\title{
$\approx \therefore$
}

NASA Technical Memorandum 102077

AIAA-89-0438

\section{Effect of Reduced Aft Diameter and Increased Blade Number on High-Speed Counterrotation Propeller Performance}

Gayle E. Rose

Sverdrup Technology, Inc.

NASA Lewis Research Center Group

Cleveland, Ohio

and

Robert J. Jeracki

National Aeronautics and Space Administration

Lewis Research Center

Cleveland, Ohio

Presented at the

27th Aerospace Sciences Meeting

sponsored by the American Institute of Aeronautics and Astronautics

Reno, Nevada, January 9-12, 1989

\section{N/Sก}

(NASA-TM-102017) EFFECT OF REDUCED AFT 
EFFECT OF REDUCED AFT DIAMETER AND INCREASED BLADE NUMBER ON

\title{
HIGH-SPEED COUNTERROTATION PROPELLER PERFORMANCE
}

\author{
Gayle E. Rose* \\ Sverdrup Technology, Inc. \\ NASA Lewis Research Center Group \\ Cleveland, Ohio 44135 \\ and \\ Robert J. Jeracki \\ National Aeronautics and Space Administration \\ Lewis Research Center \\ Cleveland, Ohio 44135
}

\section{SUMMARY}

Performance data of 0.17-scale model counterrotation pusher propeller configurations were taken in the NASA Lewis 8 - by 6 -Foot Supersonic Wind Tunnel at Mach numbers of $0.66,0.71,0.75$, and 0.79 . These tests investigated the aerodynamic performance of the unducted fan (UDF) demonstrator propeller engine developed in a joint program by General Electric and NASA. Data were recorded to show the effect on counterrotation propeller cruise efficiency of two takeoff noise-reduction concepts. These two concepts are reduced aft blade diameter and increased forward blade number. The four configurations tested were a baseline ( $F / / A 18 / 8$ ) configuration, a reduced aft diameter ( $F 1 / A 3$ 8/8) configuration, an increased forward blade number ( $F / / A 19 / 8$ ) configuration, and a combination of the latter two ( $F / / A 39 / 8$ ) configurations. Data were collected with a complex counterrotation propeller test rig via rotating thrust and torque balances and pressure instrumentation. Data comparisons documented the power differences between the baseline and the reduced aft diameter concepts. Performance comparisons to the baseline configuration showed that reducing the aft blade diameter reduced the net efficiency, and adding a blade to the front rotor increased the net efficiency. The combination of the two concepts showed only slightly lower net efficiency than the baseline configuration. It was also found that the counterrotation demonstrator propeller model (F7/A7 8/8) configuration outperformed the baseline (F1/Al 8/8) configuration.

\section{SYMBOLS}

$$
\begin{array}{ll}
\text { AF } & \text { activity factor, } 6250 \int_{(r / R)}^{.0}\left(b / D_{p}\right)(r / R)^{3} d(r / R) \\
A_{A} & \text { propeller annulus area, } \mathrm{ft}^{2} \\
b & \text { local blade chord, } \mathrm{ft} \\
D & \text { propeller diameter, } \mathrm{ft} \\
d(r / R) & \text { elemental radius ratio }
\end{array}
$$

\footnotetext{
*Presently a NASA Lewis Research Center employee.
} 


$$
\begin{array}{ll}
J & \text { advance ratio, } V_{0} /\left(n D_{p}\right) \\
n & \text { rotational speed, } r p s \\
P Q A & \text { power coefficient, } 550 S H P /\left(\rho n^{3} D_{p}^{3} A_{A}\right) \\
P Q A / J^{3} & \text { power loading parameter, } 550 S H P /\left(\rho V_{0}^{3} A_{A}\right) \\
R & \text { radius, } f t \\
r & \text { local blade radius, } f t \\
\text { SHP } & \text { shaft horsepower } \\
T & \text { thrust, lb } \\
V & \text { velocity, fps } \\
\beta & \text { blade angle at a nominal three-quarter tip radius, degrees } \\
n & \text { propeller efficiency, } \mathrm{TV}_{0} / \mathrm{SHP} \times 100, \text { percent } \\
\rho & \text { air density, slugs/ft }
\end{array}
$$

Subscripts:

$\begin{array}{ll}P & \text { propeller } \\ T & \text { total } \\ 0 & \text { freestream condition } \\ 1 & \text { forward rotor } \\ 2 & \text { aft rotor }\end{array}$

\section{INTRODUCTION}

Since the early seventies, the NASA Lewis Research Center has been investigating the advanced propeller concept as a fuel-efficient alternative to the conventional turbofan engine used on most large commercial aircraft. The target aircraft of this engine concept is the commercial transport aircraft which operates in the 0.6 to 0.8 Mach range. A review of NASA research on advanced propellers is given in reference 1.

Concepts incorporated in the single rotation designs were higher blade sweep, larger blade chord, and a larger number of blades than seen on conventional turboprops ( $\mathrm{fig} .1$ ). Another advanced concept is counterrotation, in which two rows of propeller blades rotate in opposite directions. This design allows the recovery of several percent in effictency by reducing the induced swirl losses in the propeller slipstream. 
Flight testing of a highly loaded, large hub/tip ratio counterrotation pusher propeller engine concept was begun in 1987. The demonstrator propeller engine was flown on both a Boeing B-727 and a McDonald Douglas MD-80 ( $f$ ig. 2 ). On the 8-727, the engine was flown in an $8 / 8$ configuration (eight blades on the front rotor and eight blades on the rear). On the MD-80 aircraft, an $8 / 8$ as well as an increased forward blade number (10/8) configuration were flown.

More information on the demonstrator propeller engine can be found in reference 2 .

The data presented in this report are only part of the data which were collected in a series of tests done in the Lewis 8 - by 6-Foot Supersonic Wind Tunnel. These tests were done with a counterrotation pusher propeller test rig (CRP/PTR), and they investigated the aerodynamic performance of the demonstrator model configuration as well as several other configurations. Details on the tests done with the CRP/PTR at cruise conditions and on the performance of the demonstrator model configuration are presented in reference 3 . Lowspeed data were also collected with the CRP/PTR (ref. 4).

The purpose of the tests which led to this paper was to experimentally investigate the effect on counterrotation propeller cruise efficiency of two takeoff noise-reduction concepts, namely, reduced aft propeller diameter and increased forward blade number. Data are also presented that compare the baseline configuration and the demonstrator model configuration. Acoustic data collected in conjunction with these tests are presented in reference 5 .

\section{TEST FACILITIES}

\section{Wind Tunnel}

This test was performed in the NASA Lewis 8- by 6-Foot Supersonic Wind Tunnel. The tunnel has a 14-ft-long perforated test section with 5.8-percent porosity to minimize the model-wall interactions. More details on this facility can be found in reference 6 .

The tunnel is capable of operating at Mach 0.36 to 2.0 , but was run at Mach $0.66,0.71,0.75$, and 0.79 for this test. A calibration of the wind tunnel test section, which accounted for model interaction effects with the CRP/ PTR installed, was done after performance testing was completed. The results of this calibration are presented in reference 7 and show that the actual test Mach numbers were slightly lower than those set during the test. The Mach numbers presented in this report have been corrected on the basis of this calibration.

\section{Propeller Models and Configurations}

Table I lists the design characteristics for the models discussed in this paper. Forward rotor blades are designated with an "F" prefix, while aft rotor blades are designated with an "A" prefix. All blades, except the A3 blade, have a hub-to-tip diameter ratio of approximately 0.42 when mounted on the CRP/ PTR. All blades were made with a composite shell built up over a titanium spar. 
Figure 3 shows the $F 1, A 1$, and $A 3$ blades. The $F 1$ and $A l$ blades have a similar planform and were used in the baseline (FI/A1) configuration. The A3 blade is seen to have a cropped tip and an increased chord. The reduced aft diameter $\mathrm{FI} / \mathrm{A} 3$ configuration was tested with the same forward rotor blade as the $\mathrm{Fl/Al}$ configuration, but with a different aft rotor blade. The A3 blades were designed (on the basis of the $A l$ blade) with a 12-percent smaller diameter in order to eliminate noise caused by the rear rotor blades interacting with tip vortices from the forward rotor blades. Consequentiy, the rear blade chord was increased to allow the front and rear blade rows to operate at equal power at matched speeds.

The baseline configuration, $\mathrm{Fl} / \mathrm{Al}$, consisted of eight blades on each rotor, 8/8. A ninth blade was added to the forward rotor, $9 / 8$, to determine the effect of increased forward blade number on counterrotation propeller acoustic and aerodynamic performance. This $9 / 8$ configuration reduced the perblade loading on the front rotor blades.

The Fl/Al blade planforms were similar to those of the initial demonstrator model blades F7/A7 ( $f$ ig. 4) but had a slightly less rounded tip and lower cambered airfoil sections.

\section{Propeller Test Rig}

The propeller models were tested with the CRP/PTR, which is shown in a cross-sectional view of the test section in figure 5 and mounted in the wind tunnel in figure 6 . Reference 8 gives a detailed description of the CRP/PTR.

The propeller blades are mounted on two rotors that are connected to pneumatically powered turbines by concentric drive shafts. The two-stage turbines are located in the turbine housing and are capable of providing up to 700 shp per rotor. The turbines are powered by 450-psi high-pressure air heated to $660^{\circ} \mathrm{R}$.

From an aft-looking-forward position, the forward rotor and inner shaft rotate in a counterclockwise dilection, while the rear rotor and outer shaft rotate in a clockwise direction. The distance between the rotors, 4.16 in., is measured from the blade pitch-change axis of the forward rotor to the blade pitch-change axis of the aft rotor.

Pressures measured by taps located on the surface of the nacelle and in the rotor cavities are used in the calculation of nacelle forces and internal rotor cavity forces. Pressure taps located on the surface of the afterbody and in the rear rotor cavity are connected to electronically scanned pressure (ESP) modules mounted outside of the test section. Taps located on the forebody and in the forward rotor cavity are connected to ESP modules which are located in the forebody. Forebody instrumentation wires are routed through a hollow shaft that runs down the center of the two rotating shafts and then down through the support strut where they are connected to the data acquisition system. 


\section{Rotating Balances}

Each rotor is mounted on a rotating balance that measures the thrust and torque produced by each propeller. Temperature and centrifugal force are measured on each balance. Signals from each balance are transmitted via a telemetry system to an on-board antenna assembly which connects to a monitoring station in the control room.

Static calibrations of the balances were done, and coefficients were supplied, by the manufacturer. Before the testing began, static calibrations were made in the wind tunnel. These calibrations confirmed the static coefficients.

Dynamic spin calibration checks were made on four of six identical balances at a contractor facility. The checks confirmed the analyses, which predicted a reduction in measured thrust and a slight reduction in measured torque as a function of rotational speed. The magnitude of the corrections to thrust and torque are documented in reference 3 .

\section{PROGRAM DESCRIPTION}

Four configurations were tested, including a baseline, a reduced aft diameter, an increased forward blade number, and a combination of the latter two configurations. The test matrix for the four configurations is shown in table II. The design blade angle settings were tested for each configuration. Because of time limitations, one off-design blade angle setting was tested for only the $8 / 8$ configurations.

The blade angle $(\beta)$ settings could only be changed before or after a tunnel run; therefore, blade angle settings remained constant for the entire run. The blade angle is measured statically at a nominal three-quarter blade radius. This radius is defined as 9.188 in. for all blades except the reduced diameter blade. For the reduced diameter blade, $A 3$, the three-quarter radius is defined as $7.877 \mathrm{in}$. During operation, the blade angle changes because of aerodynamic loading and centrifugal forces.

Each tunnel run consisted of data taken at several Mach numbers. At each Mach number, data were taken at several power conditions, varying from windmill to the maximum available power. In some cases, maximum power could not be reached because of the design limits set on the balance (thrust of $4001 \mathrm{~b}$, torque of $450 \mathrm{ft}-1 \mathrm{~b}$, or speed of $9000 \mathrm{rpm}$ ). All data were taken with matched front and rear rotor speeds. Matched speeds represent a speed on the rear rotor which was $50 \mathrm{rpm}$ higher than that set on the front rotor. This was done to prevent rig vibrations from exceeding safety limits.

After the minimum power point was set, speed was varied in 200 rpm increments from the minimum power point, until a maximum power point was reached. Whenever possible, data points were also taken at 105 to 80 percent of design speed in increments of 5 percent while decreasing the rotor speeds from the maximum power point.

In all runs, blades were instrumented with strain gages in order to monitor blade stresses. Results on a different configuration show a penalty of 0.7 percent at Mach 0.71 and of 1.6 percent at Mach 0.79 for strain gage 
installation. However, data showing the effect of strain gages were not sufficient to make a change in the data of this report.

\section{RESULTS AND DISCUSSION}

\section{Basic Propeller Data}

Aerodynamic performance data from all tunnel runs are shown in figures 7 to 14. The figures pertaining to the $F / / A 1$ configurations are grouped in figures 7 to 10, while those of the Fl/A3 configurations appear in figures 11 to 14. Data on the $9 / 8$ configurations are not separated from that of the $8 / 8$, but are marked for identification. Each figure presents total power coefficient ( $P Q A T)$, net efficiency ( $n_{n e t}$ ), and aft-to-forward torque ratio (RTO) variations with advance ratio (J). These data are shown at a constant Mach number and define the propeller operating condition. (The design operating point is defined with an advance ratio of 2.81 , a power coefficient of 4.16, and a torque ratio of 1.0.) Also shown with each figure are the corresponding net efflciency variations with power loading parameter $\left(P A_{T} / J 3\right)$.

Net efficiency ( $n_{n e t}$ ) is calculated from the net thrust of the blades only, which includes a correction to account for the effect of the change in pressure drag of the nacelle due to the interaction with the propeller. The propeller net thrust is the thrust force measured by the rotating force balances, corrected for the internal rotor cavity pressure forces, the external rotor drag forces, and the change in the external rotor and nacelle drag forces caused by the installed propeller. For a more complete review of the calculation of net propeller thrust, see reference 3 .

Because of the large hub-to-tip ratio of this model, all power coefficient data presented are based on propeller annulus area. In the dimensionless form, the performance parameters presented are referenced to the forward rotor.

Part (a) of these figures presents propeller net efficiency (nnet) and power coefficient $\left(P Q A_{T}\right)$ versus advance ratio $(J)$. In figure $8(a)$, the power and efficiency data taken with the design blade angle settings ( $\beta=57.1 \%$ $54.8^{\circ}$ for the $8 / 8$ configuration and $\beta=57.2^{\circ} / 54.3^{\circ}$ for the $9 / 8$ configuration) are nearly identical for the $8 / 8$ and $9 / 8$ configurations. By comparison, the data taken with the off-design blade angle settings $\left(\beta=59.5^{\circ} / 56.5^{\circ}\right)$ are offset from that taken with the design settings. This is because the data are presented as a function of advance ratio and the change in blade angle settings causes a change in power. These same trends are seen in the F1/A3 data of figures $11(a), 12(a)$, and $13(a)$.

Part (b) presents net efficiency versus the power loading parameter $\left(P Q A_{T} / J^{3}\right)$ in order to show the sensitivity of propeller performance with power. The power loading parameter is a form of the power nondimensionalized by freestream parameters. The power loading parameter allows for comparisons of data from various blade angle settings at constant power. Thus, the data of the $8 / 8$ configuration shown in figures $8(b), 11(b), 12(b)$, and $13(b)$ tend to fall on top of each other. Propeller performance based on the power loading parameter is used in the creation of the summary figures which will be discussed later. 
Part (c) of these figures presents the aft-to-forward torque ratio (RTQ) versus advance ratio ( $\mathrm{J}$ ). The steepness of the data curves is characteristic of high-speed data taken with these counterrotation propellers. The front rotor windmill speed was much less than that of the rear rotor (on the order of $700 \mathrm{rpm})$. This made it necessary to power or load up the front rotor in order to match speeds before power was applied to the rear rotor. Therefore, the rear rotor torque started out much lower than did the front.

\section{Power Comparisons}

Examination of the $\mathrm{Fl} / \mathrm{Al}$ data at different Mach numbers reveals that there is very little change in the torque ratio at the design advance ratio $(J=2.81)$. However, a similar examination of $F I / A 3$ data does not show this trend. At the design advance ratio for Fl/Al, figure $7(\mathrm{c})$ (Mach 0.66) shows a torque ratio of 1.12 , figure $8(\mathrm{C})$ (Mach 0.71 ) one of 1.10 , and figure $9(\mathrm{C})$ (Mach 0.75 ) one of 1.08 . At the design advance ratio for $F 1 / A 3$, figure $11(\mathrm{C}$ ) (Mach 0.66) shows a torque ratio of 0.92 , figure $12(\mathrm{c})$ (Mach 0.71 ) one of 1.04 , and figure $13(\mathrm{c})$ (Mach 0.75 ) one of 1.08 .

In order to investigate the difference in torque ratio trends, the individual rotor power coefficients are shown for all data taken (figs. 15 to 20). In order to keep an equivalent scale, the forward blade diameter and annulus area were used as the reference diameter and annulus area in the calculation of both the forward rotor and aft rotor power coefficients. The data are shown plotted with the advance ratio (J) calculated from forward rotor parameters. The top half of the figure shows the forward rotor power coefficient $\left(P Q A_{1}\right)$ and the bottom half shows the aft rotor power coefficient $\left(P Q A_{2}\right)$. Each figure represents all Mach number data collected at a constant blade angle setting.

The trends of the forward rotor power coefficient data in all figures show that power absorption goes down with increasing Mach number. In figures 17 $(F / / A 1)$ and 20 (FI/A3), the forward rotor power coefficient is seen to have nearly the same magnitude for both configurations $(\mathrm{PQA})=2.08$ for $\mathrm{Fl} / \mathrm{Al}$ at the design point, $J=2.81$ and $\mathrm{Mach}=0.71$, and $P Q A_{1}=2.07$ for $F 1 / A 3$ at the design point). In these particular data, the same blade angle was set on the front rotor for both the $F 1 / A 1$ and the $F 1 / A 3$ configurations $\left(\beta_{1}=57.2^{\circ}\right)$. The change in aft blade diameter seems to have no effect on the amount of power absorbed by the front rotor.

With an increase in Mach number, the trends of the aft rotor power coefficient $\left(P Q A_{2}\right)$ data for the Fl/AI configuration (figs. 15 to 17 ) show the same decrease in power absorbed as was seen for the forward rotor power coefficient $\left(P Q A_{1}\right)$. However, for the reduced aft diameter Fl/A3 configuration ( $f$ igs. 18 to 20), the aft rotor power coefficient data tend to collapse onto one curve. For this reason, only one fairing is shown for all Mach number data.

In figure 19, there is some deviation of the data from the fairing for the 0.79 Mach number case at the higher powers. This deviation is probably caused by compressibility effects on the $A 3$ blade, but is a small change when compared with the variation in power data of the different Mach numbers for the fullalameter blades. Because of its shorter span, the A3 blade would have a smaller tip relative Mach number at the same rotor speed than the full diameter blades. Therefore, compressibility effects on the FI and Al blades would be 
greater than on the $A 3$ blade and probably contribute to the difference in power absorption shown earlier.

An additional contribution to this difference in power absorption may be due to the fact that the A3 blade is stiffer than the FI and Al blades. The decrease in power absorbed by the $F I$ and $A l$ blades could be the result of a deflection of the blades as they load up at the higher Mach numbers. This possible deflection could cause a change in the amount of power absorbed by the blades. The stiffer A3 blade would not have as large a deflection and therefore would absorb the same power at all Mach numbers.

The trend identified by these data is also illustrated in the plots of aft-to-forward torque ratio (RTQ) versus power loading parameter ( $f$ igs. 21 to 26). Notice that the $F \mid / A 1$ torque ratio data for the different Mach numbers at the same blade angle tend to collapse onto a single curve (figs. 21 to 23). The $9 / 8$ configuration data ( $f$ ig. 23) show that the different Mach number data do separate somewhat, but not by a significant amount. However, the Fl/A3 torque ratio curves (figs. 24 to 26 ) show an increase in torque ratio at a constant power loading parameter with an increase in Mach number. Therefore, for a given blade angle, torque ratio versus power loading parameter is independent of Mach number for the Fl/Al configuration, but not for the Fl/A3 configuration.

\section{Efficiency Comparisons}

In order to compare the performance of the different configurations, it is necessary to evaluate the efficiencies at the same power coefficient and advance ratio. The only place where the four configurations of this report can be directly compared is at a 121 percent power point $\left(J=2.70, P Q A_{T}=4.46\right.$ ) of Mach 0.71 . At this point, the two $9 / 8$ configurations have a matching power coefficient and advance ratio and there are enough data from the $8 / 8$ configurations to allow for extrapolation to match the conditions of the $9 / 8$ configurations.

Table III shows that at this 121 percent power point, reducing the aft blade diameter decreased performance, and increasing the forward blade number increased performance. The efficiency of the baseline (FI/Al 8/8) configuration is 77.6 percent. This is better than that of the reduced aft diameter (F1/A3 8/8) configuration by 2.2 percent. However, it is not as good as the increased forward blade number ( $F / / A 19 / 8$ ) configuration, which has an efficiency of 78.3 percent. The incorporation of the two noise-reduction concepts, which led to the $F 1 / A 39 / 8$ configuration, showed improved performance over the F1/A3 $8 / 8$ configuration of 0.9 percent.

Also shown in table III are comparisons of the $8 / 8$ configurations and the demonstrator model ( $F 7 / A 7$ 8/8) configuration (ref. 3) made at the 120 percent power point $(J=2.81, P Q A T=4.99)$ of Mach 0.71 . The efficiency level of the $\mathrm{Fl} / \mathrm{Al}$ configuration is nearly the same as it was at the 121 percent power point. However, the efficiency level of the Fl/A3 went up 0.4 percent. These values are seen to be lower than those of the F7/A7 configuration, which had an efficiency of 80.2 percent.

The performance of the four configurations can be evaluated at the design power loading $\left(P Q A_{T} / J^{3}=0.1875\right)$. However, the advance ratio at these 
points, al though near, does not equal design ( $J=2.81$ ). Other data show that near the 100 percent design point, the efficiency is insensitive to small changes in advance ratio (ref. 3). Therefore, an assessment of the 100 percent power loading performance of the four configurations was made ( $f i g .27$ ) and compared with the performance of the F7/A7 $8 / 8$ configuration (ref. 3 ). The points used in these comparisons were evaluated at the design power loading and as close as possible to the design advance ratio. The magnitude of the difference between the advance ratio at which the evaluations were made and the design value was no more than 0.09 (a difference of 3 percent).

Beside the performance comparisons, the ideal induced efficiency for an $8 / 8$ configuration is also shown in figure 27 . The ideal induced efficiency represents the efficiency of an optimally loaded propeller operating in a nonviscous fluid (ref. 9). Calculations of ideal efficiency are based on the momentum theory with a correction for tip losses. For counterrotation, the prediction includes no loss in efficiency due to swirl. Therefore, differences between ideal and measured efficiency represent losses that are caused by viscous, compressibility, and residual swirl effects.

The same observations can be seen in figure 27 as were seen in table III. Reducing aft blade diameter decreased performance, and increasing forward blade number increased performance. In addition, the efficiency of the $\mathrm{Fl} / \mathrm{Al} 8 / 8$ configuration decreased as compared with the F7/A7 8/8 configuration.

A comparison of the performance of the Fl/Al $8 / 8$ configuration with the F1/A3 $8 / 8$ configuration reveals that the efficiency level of the $\mathrm{Fl} / \mathrm{Al}$ is higher than that of the FI/A3 ( $f \mathrm{gg} .27$ ). At the design Mach number of 0.72 , the Fl/Al configuration efficiency is seen to be 78.1 percent and that of the $F 1 / A 3$ configuration is 76.5 percent. This represents a reduction in efficiency, caused by the reduced aft diameter blades, of approximately 1.6 percent.

The reduction in efficiency of the Fl/A3 configuration is presumably due to the shortened span of the $A 3$ blade. Although the A3 blade has an increased chord and the blade angle of the blade was set to produce matched torque at matched speeds, it cannot recover the swirl that a full-size blade would have recovered. It is possible that the $A 3$ blade overcompensates for swirl over the length of its span, but allows uncorrected swirl passage in the region outboard of the cropped tip. Similarly, the $A 3$ blade cannot produce the same induced flow conditions at the front rotor that the Al blade does. However, any change in induced flow to the front rotor does not seem to be affecting the power requirements of the forward blades. In the results shown, the $F 1$ blade seems to absorb the same power when acting with the $A 3$ blade as with the $A$ l blade. Nonetheless, some type of flow documentation would be required in order to say what factors are actually contributing to the decline in efficiency of the F1/A3 configuration.

The ideal induced efficiency for the $9 / 8$ configuration is 89.7 percent, approximately 0.2 percent higher than the value shown (fig. 27) for the $8 / 8$ configuration. However, the $\mathrm{Fl} / \mathrm{Al} 9 / 8$ configuration improves efficiency by 1.0 percent at the design Mach number of 0.72 . In view of the smaller distance between blades for the 9-bladed rotor relative to the 8-bladed rotor, higher compressibility losses could be expected. However, any increase in compressibility losses developed because of the increased forward blade number configuration was offset by other gains. 
When the nine-bladed rotor operates at the same power as the eight-bladed rotor, improvements in efficiency may stem from lower losses resulting from reduced loading per blade on the front rotor or possibly from an improved loading distribution on the front rotor. If advance ratio and power loading are the same for both the nine- and eight-bladed rotors, then in order for the efficiency to go up, the thrust must have improved. Thus, the additional blade does provide an additional amount of thrust.

Both of the takeoff noise-reduction concepts are incorporated in the Fl/A3 $9 / 8$ configuration. At the design Mach number of 0.72 , the $\mathrm{Fl} / \mathrm{A} 39 / 8$ configuration has a net efficiency of 77.3 percent, which is only slightly lower (approximately 0.8 percent) than the $\mathrm{Fl} / \mathrm{Al} 8 / 8$ configuration ( $\mathrm{fig} .27$ ). The incorporation of the $9 / 8$ configuration into the $\mathrm{Fl} / \mathrm{A} 3$ model, therefore, allows for the recapture of part of the loss in efficiency resulting from the reduced aft diameter blades.

Also shown in figure 27 is the performance of the demonstrator (F7/A7 8/8) configuration. At the design Mach number of 0.72 , the efficiency of the $F 7 / A 7$ is 79.6 percent, which is 1.5 percent higher than that of the Fl/Al $8 / 8$ configuration. In the region of Mach 0.66 , the performance of the $\mathrm{F} / / \mathrm{Al} 9 / 8 \mathrm{config}-$ uration is higher than that of the $F 7 / A 78 / 8$ configuration. With this exception, the performance of the $F 7 / A 78 / 8$ configuration is better than that of all other configurations shown. On the basis of the performance of the configurations shown, it would appear that the $F 7 / A 7$ configuration efficiency would improve if it were flown in a $9 / 8$ configuration.

Noise studies show that there is a significant noise reduction at cruise (ref. 5) as well as at takeoff conditions (ref. 10) with the A3, reduced aft diameter, blades. Nolse studies on increased blade number configurations show lower noise levels with increased blade number in either biade row (ref. 11). Thus, in the overall design of an engine concept, both the reduced aft-diameter blade and the increased forward blade number configurations represent promising tradeoffs between propeller noise and efficiency.

\section{SUMMARY OF RESULTS}

The cruise performance of two takeoff noise-reduction concepts was documented. A baseline and reduced aft diameter model were tested in both a baseline and an increased forward blade number configuration. Data were collected at Mach numbers of $0.66,0.71,0.75$, and 0.79 in the NASA Lewts 8 - by 6-Foot Supersonic Wind Tunnel. Tests were conducted with a counterrotation pusher propeller test rig.

Comparisons were made at the 100 percent power loading condition. The efficiency of the baseline configuration, $\mathrm{Fi} / \mathrm{Al} 8 / 8$, was 78.1 percent at the design Mach number of 0.72 . The reduced aft diameter (F//A3 8/8) propeller showed lower performance (on the order of 1.5 percent) than the baseline propeller. The increased forward blade number ( $\mathrm{Fl} / \mathrm{Al}$ 9/8) configuration showed higher performance (on the order of 1.0 percent) than the baseline configuration at the design Mach number. The incorporation of the two takeoff noisereduction concepts ( $\mathrm{Fl} / \mathrm{A3}$ 9/8) resulted in only slightly lower cruise performance (on the order of 0.8 percent) than the baseline configuration. The efficiency was higher (on the order of 1.4 percent) for the demonstrator model 
(F7/A7 8/8) configuration than for the baseline model (Fl/A1 8/8) configuration at the design Mach number.

Changing from a full-size aft blade (Al) to the reduced aft diameter ( $A 3$ ) blade seems to have no effect on the power requirements of the front rotor. The $A 3$ blade shows no change in power absorption with a change in Mach number. The aft-to-forward torque ratio as a function of power loading parameter shows a dependence on Mach number for only the reduced aft diameter (FI/A3) configurations.

\section{REFERENCES}

1. Groeneweg, J.F.; and Bober, L.J.: NASA Advanced Propeller Research. NASA TM-101361, 1988.

2. Stuart, A.R.: The Unducted Fan Engine. AIAA Paper 85-1190, July 1985.

3. Jeracki, R.J.; and Rose, G.E.: Effects of Mach Number, Loading, and Blade Angle on High-Speed Performance of the F7/A7 Highly Loaded Counterrotation Propeller. NASA TP-2927, 1990.

4. Hughes, C.E.; and Gazzaniga, J.A.: Summary of Low-Speed Wind Tunnel Results of Several High-Speed Counterrotation Propeller Configurations. AIAA Paper 88-3149, July 1988 (NASA TM-100945).

5. Dittmar, J.H.; and Stang, D.B.: Noise Reduction for Model Counterrotation Propeller at Cruise by Reducing Aft-Propeller Diameter. NASA TM-88936, 1987.

6. Swallow, R.J.; and Aiello, R.A.: NASA Lewis 8- by 6-Foot Supersonic Wind Tunne1. NASA TM X-71542, 1974.

7. Stefko, G.L.; and Jeracki, R.J.: Porous Wind Tunnel Corrections for Counterrotation Propeller Testing. AIAA Paper 88-2055, May 1988 (NASA TM-100873).

8. Delaney, B.R., et al.: A Model Propulsion Simulator for Evaluating Counter Rotating Blade Characteristics. SAE Paper 861715, Oct. 1986.

9. Standard Method of Propeller Performance Estimation, Society of British Aircraft Constructors, London, 1939.

10. Woodward, R.P.; and Gordon, E.B.: Noise of a Model Counterrotation Propeller With Reduced Aft Rotor Diameter at Simulated Takeoff/Approach Conditions (F//A3). AIAA Paper 88-0263, Jan. 1988 (NASA TM-100254).

11. Woodward, R.P.: Noise of a Model High Speed Counterrotation Propeller at Simulated Takeoff/Approach Conditions (F7/A7). AIAA Paper 87-2657, Oct. 1987 (NASA TM-100206). 
TABLE I. - COUNTERROTATION PROPELLER MOOEL BLADE CHARACTERISTICS

[Cruise Design Parameters are as follows: Mach number, 0.72; altitude, $35000 \mathrm{ft}$; power loading, $55 \mathrm{SHP} / \mathrm{O}_{\text {prop; }}^{2}$ advance ratio, 2.81; power coefficient, 4.16; aft-to-forward torque ratio, 1.0; tip speed, 780 fps (665 fps for A3).]

\begin{tabular}{|c|c|c|c|c|}
\hline $\begin{array}{c}\text { Blade } \\
\text { mode1 }\end{array}$ & $\begin{array}{c}\text { Activity factor, } \\
\text { AF, } \\
\text { per blade }\end{array}$ & $\begin{array}{c}\text { Tip sweep } \\
\text { angle, } \\
\text { deg }\end{array}$ & $\begin{array}{c}\text { Reference } \\
\text { diameter, } \\
\text { in. }\end{array}$ & $\begin{array}{c}\text { Ratio of hub } \\
\text { diameter to } \\
\text { propeller diameter }\end{array}$ \\
\hline F1 & 150 & 33 & 24.60 & 0.424 \\
A1 & 150 & 30 & 23.92 & .415 \\
A3 & 2240 & 22 & 20.98 & .473 \\
F7 & 150 & 34 & 24.64 & .424 \\
A7 & 150 & 31 & 23.94 & .415 \\
\hline
\end{tabular}

$a_{A}$ calculated activity factor of 125 is based on the diameter of the Al blade.

TABLE II. - TEST MATRIX

\begin{tabular}{|c|c|c|c|}
\hline $\begin{array}{l}\text { Blade model } \\
\text { (forward/aft) }\end{array}$ & $\begin{array}{c}\text { Number of } \\
\text { blades } \\
\text { (forward/aft) }\end{array}$ & $\begin{array}{c}\text { Blade angles } \\
\text { (forward/aft), } \\
\text { deg }\end{array}$ & Mach number \\
\hline $\mathrm{F} 1 / \mathrm{A} 1$ & $8 / 8$ & $\begin{array}{r}a_{57} .1 / 54.8 \\
59.5 / 56.5\end{array}$ & $\begin{array}{c}0.75,0.71,0.66 \\
0.79,0.71\end{array}$ \\
\hline$F 1 / A]$ & $9 / 8$ & $a_{57.2 / 54.3}$ & $0.75,0.71,0.66$ \\
\hline F1/A3 & $8 / 8$ & $\begin{array}{r}\mathrm{d}_{57} .6 / 58.3 \\
60.7 / 60.9\end{array}$ & $\begin{array}{c}0.75,0.71,0.66 \\
0.79,0.75,0.71,0.66\end{array}$ \\
\hline $\mathrm{F} 1 / \mathrm{A3}$ & $9 / 8$ & $a_{57.2 / 58.0}$ & $0.75,0.71,0.66$ \\
\hline
\end{tabular}

aDesign blade angle setting.

TABLE III. - PERFORMANCE COMPARISONS AT MACH 0.71

\begin{tabular}{|c|c|c|}
\hline Configuration & $\begin{array}{c}121 \text { percent design } \\
\text { power loading, } \\
=2.70, P Q A_{T}=4.46\end{array}$ & $\begin{array}{c}120 \text { percent design } \\
\text { power loading, } \\
=2.81, P Q A_{T}=4.99\end{array}$ \\
\hline F1/A1 8/8 & 77.6 & 77.7 \\
F1/A1 9/8 & 78.3 & -75.8 \\
F1/A3 8/8 & 75.4 & - \\
F1/A3 9/8 & 76.3 & 80.2 \\
FT/A7 8/8 & - & - \\
\hline
\end{tabular}




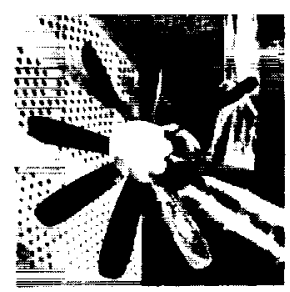

8 BLADES, $0^{\circ}$ SWEEP

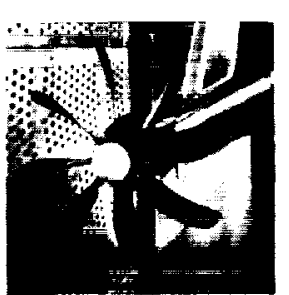

8 BLADES, $30^{\circ}$ SWEEP

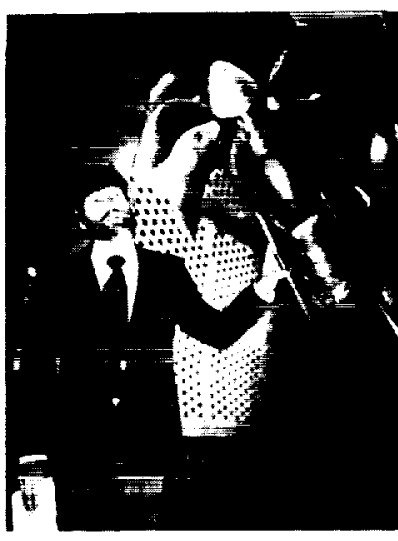

8 BLADES, $45^{\circ}$ SWEEP

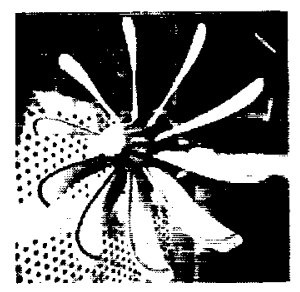

10 BLADES, $40^{\circ}$ SWEEP

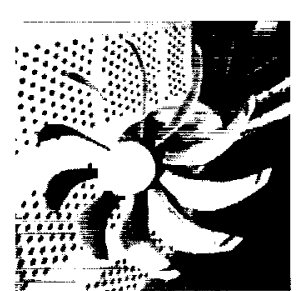

10 BLADES, $60^{\circ}$ SWEEP

FIGURE 1. - SINGLE ROTATION PROPELLER CONCEPTS STUDIED IN NASA LEWIS WIND TUNNELS.

ORIGINAL PAGE

BLACK AND WHITE PHOTOGRAPH 

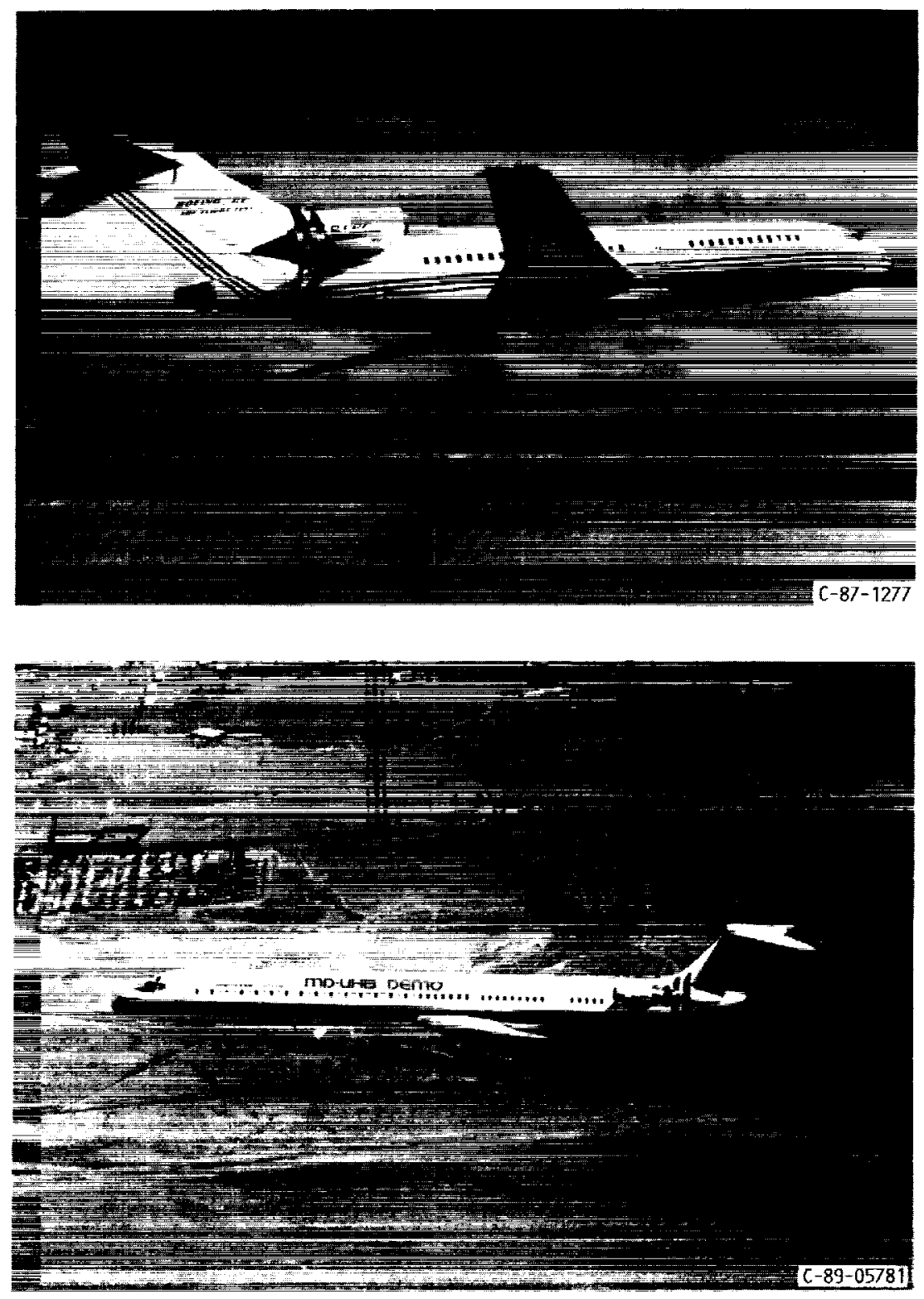

FIGURE 2. - BOEING B-727 (TOP) AND MCDONALD DOUGLAS MD-80 (BOTTOM) FLIGHT TEST AIRCRAFT CONFIGURED WITH DEMONSTRATOR PROPELLER ENGINE CONCEPT.

\author{
ORIGINAL PAGE \\ BLACK AND WHITE PHOTOGRAPH
}




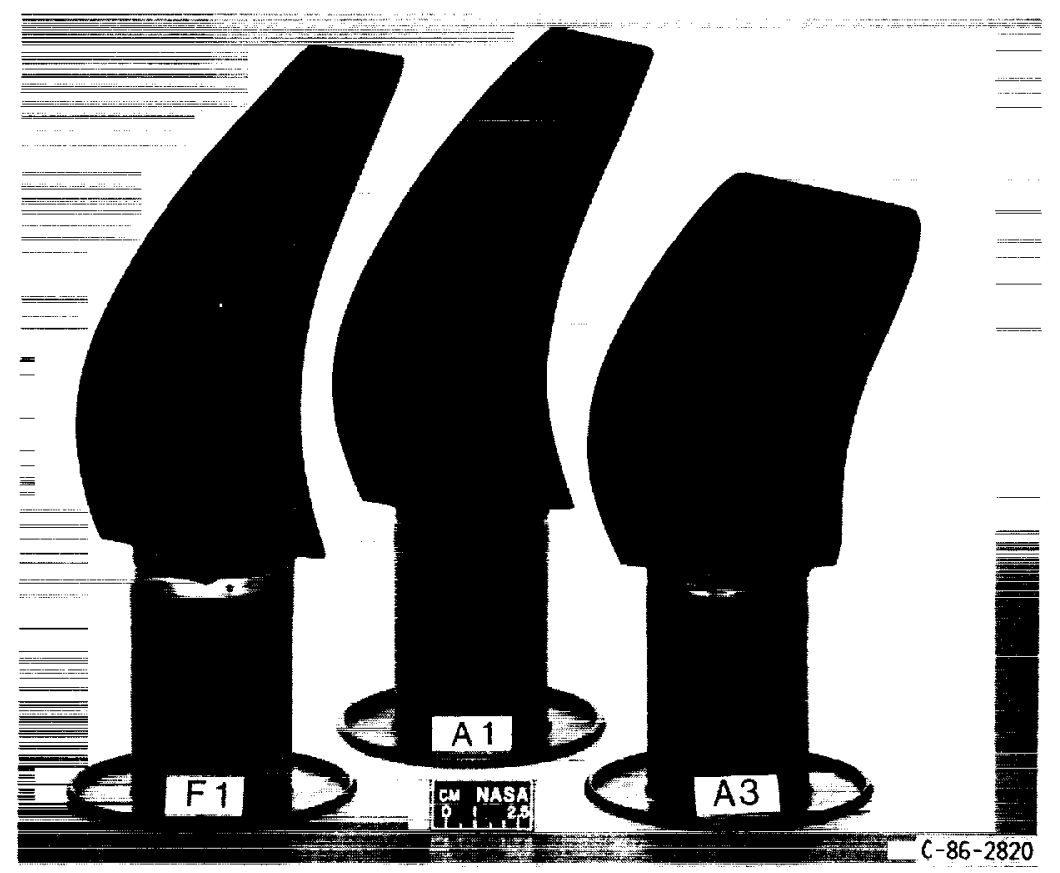

FIGURE 3. - PLANFORM VIEW OF F1, $\Lambda 1$, AND A3 COUNTERROTATION PROPELLER MODEL BLADES.

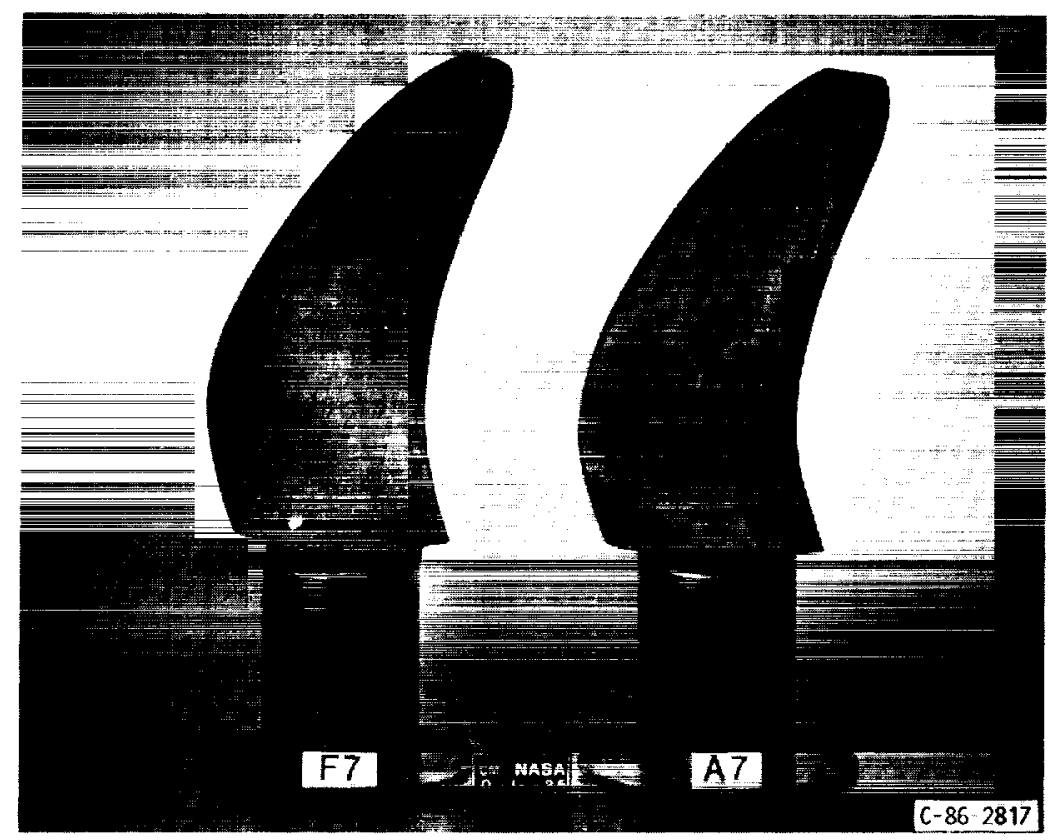

FIGURE 4. - PLANFORM VIEW OF F7 AND A7 DLMONSTRATOR ENGINE PROPCLLLR MODEL BLADES. 


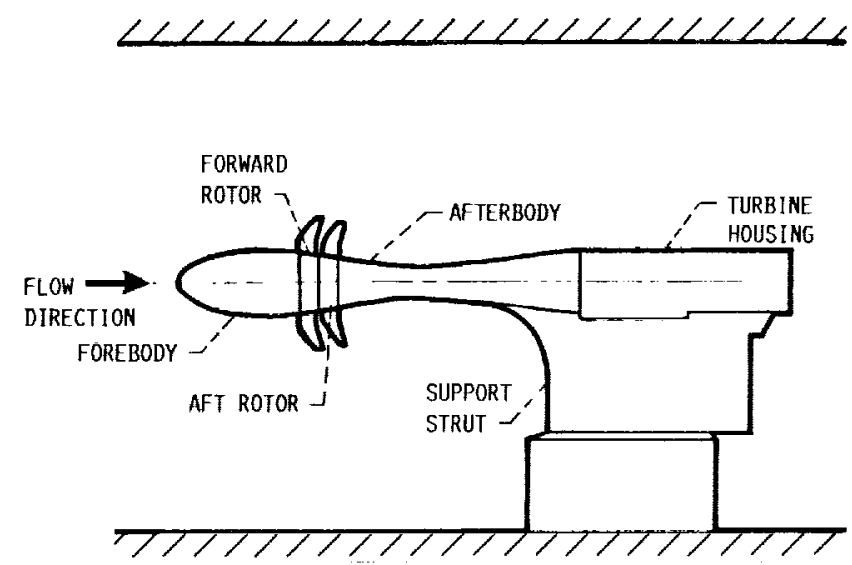

FIGURE 5. - CROSS-SECTIONAL VIEW OF COUNTERROTATION PUSHER PROPELLER TEST RIG MOUNTED IN LEWIS 8- BY 6-FOOT WIND TUNNEL,

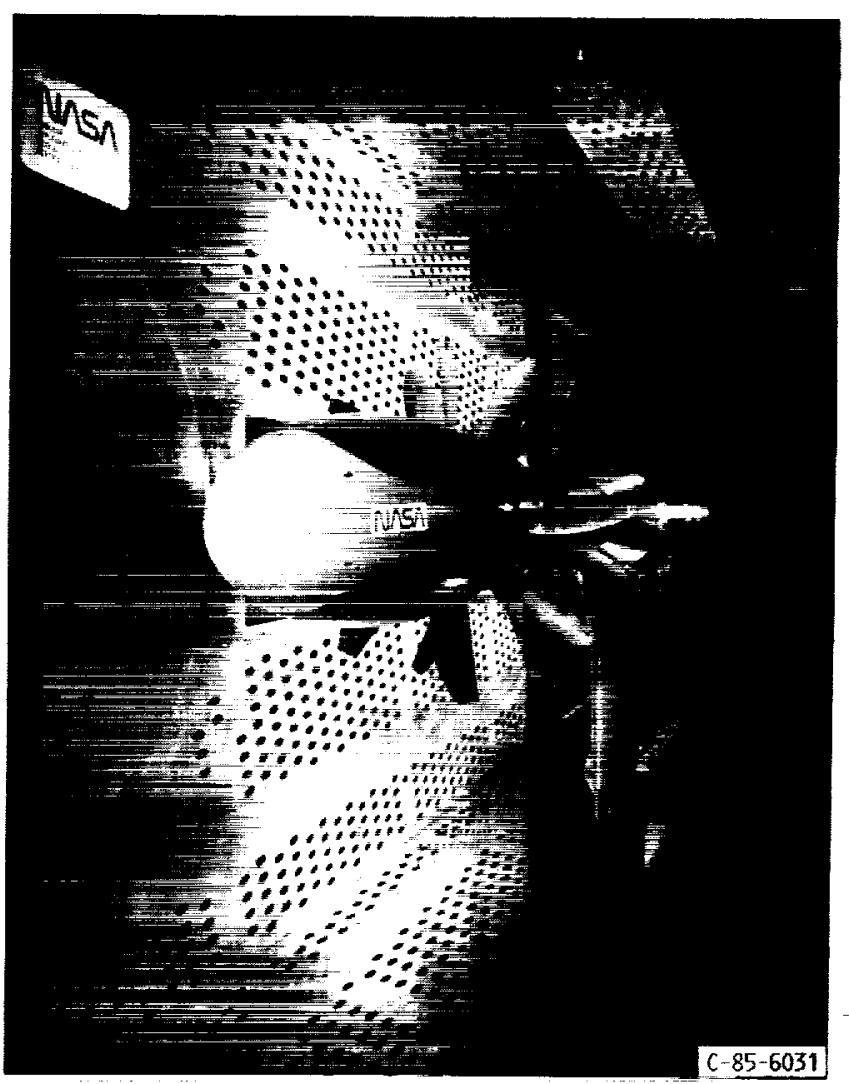

FIGURE 6. - COUNTERROTATION PUSHER PROPELLER TEST RIG MOUNTED IN LEWIS 8- BY 6-FOOTT WIND TUNHEL. 

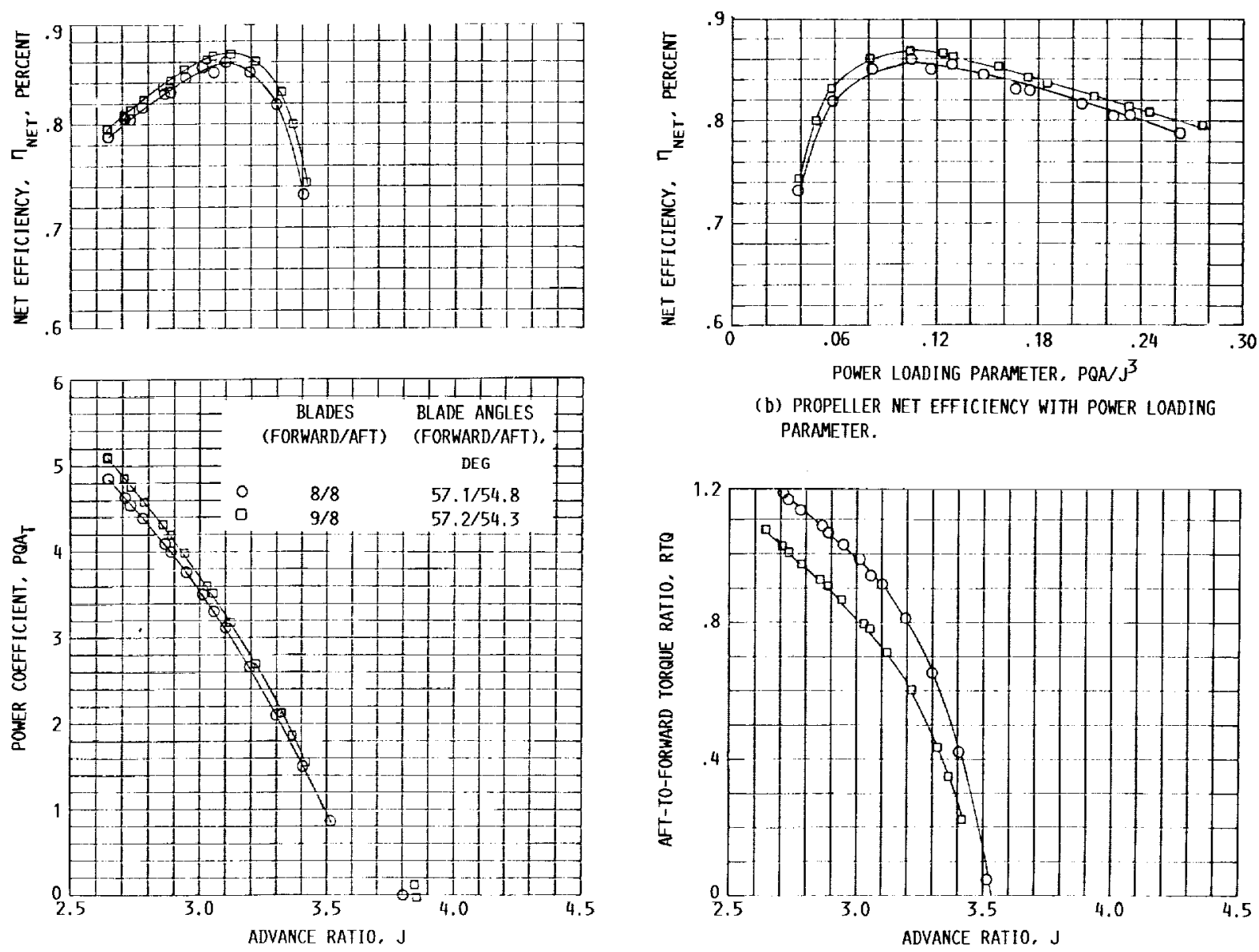

(a) PROPELLER NET EFFICIENCY AND POWER COEFFICIENT WITH ADVANCE RATIO.

FIGURE 7. - F1/AT PERFORMANCE AT MACH 0.66.

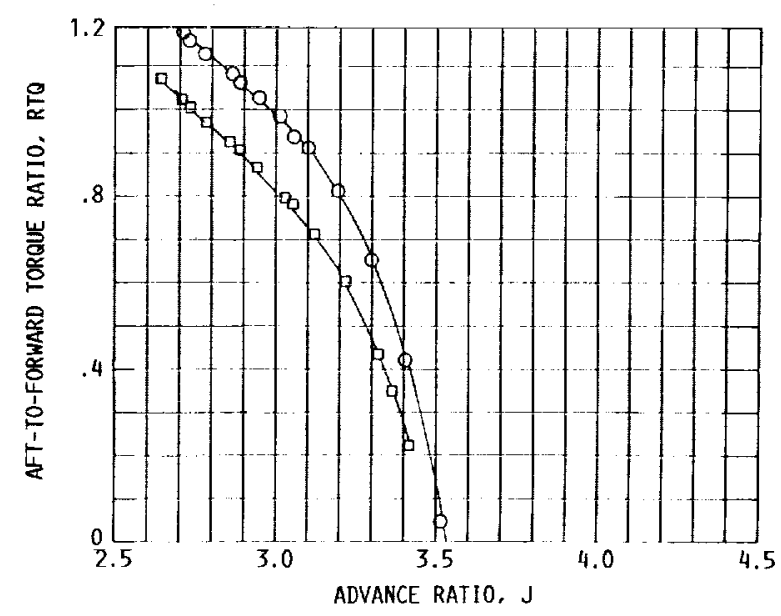

(c) AFT-TO-FORWARD TORQUE RATIO WITH ADVANCE RATIO. 

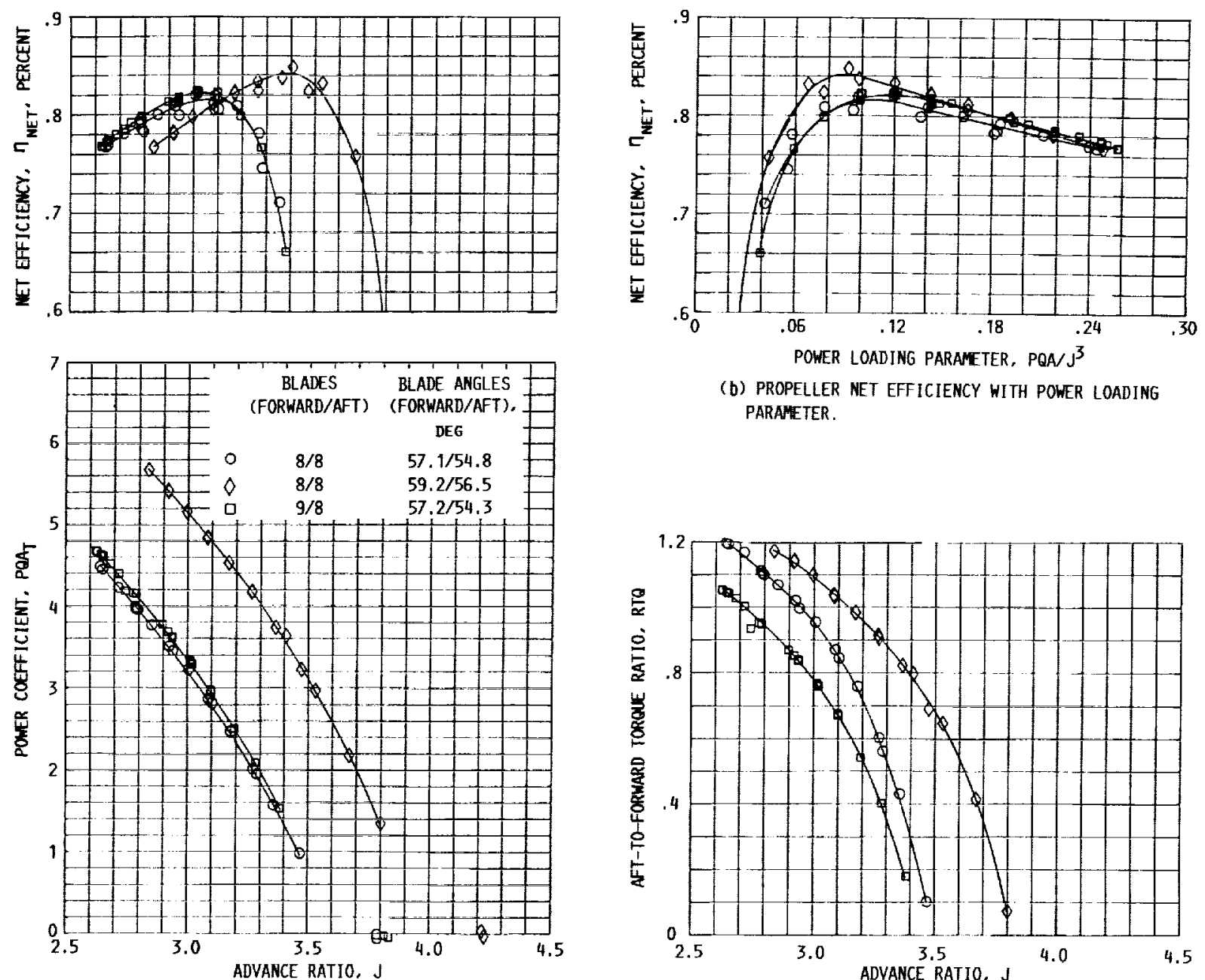

(a) PROPELLER MET EFFICIENCY AND POWER COEFFICIENT WITH ADVANCE RATIO.

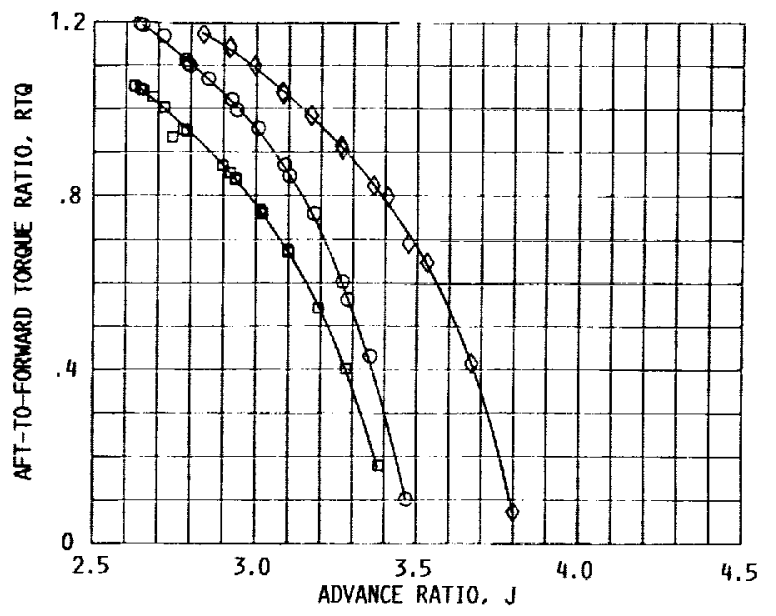

(c) AFT-TO-FORWARD TORQUE RATIO WITH ADVANCE RATIO.

FIGURE 8. - F1/A1 PERFORMANCE AT MACH 0.71. 

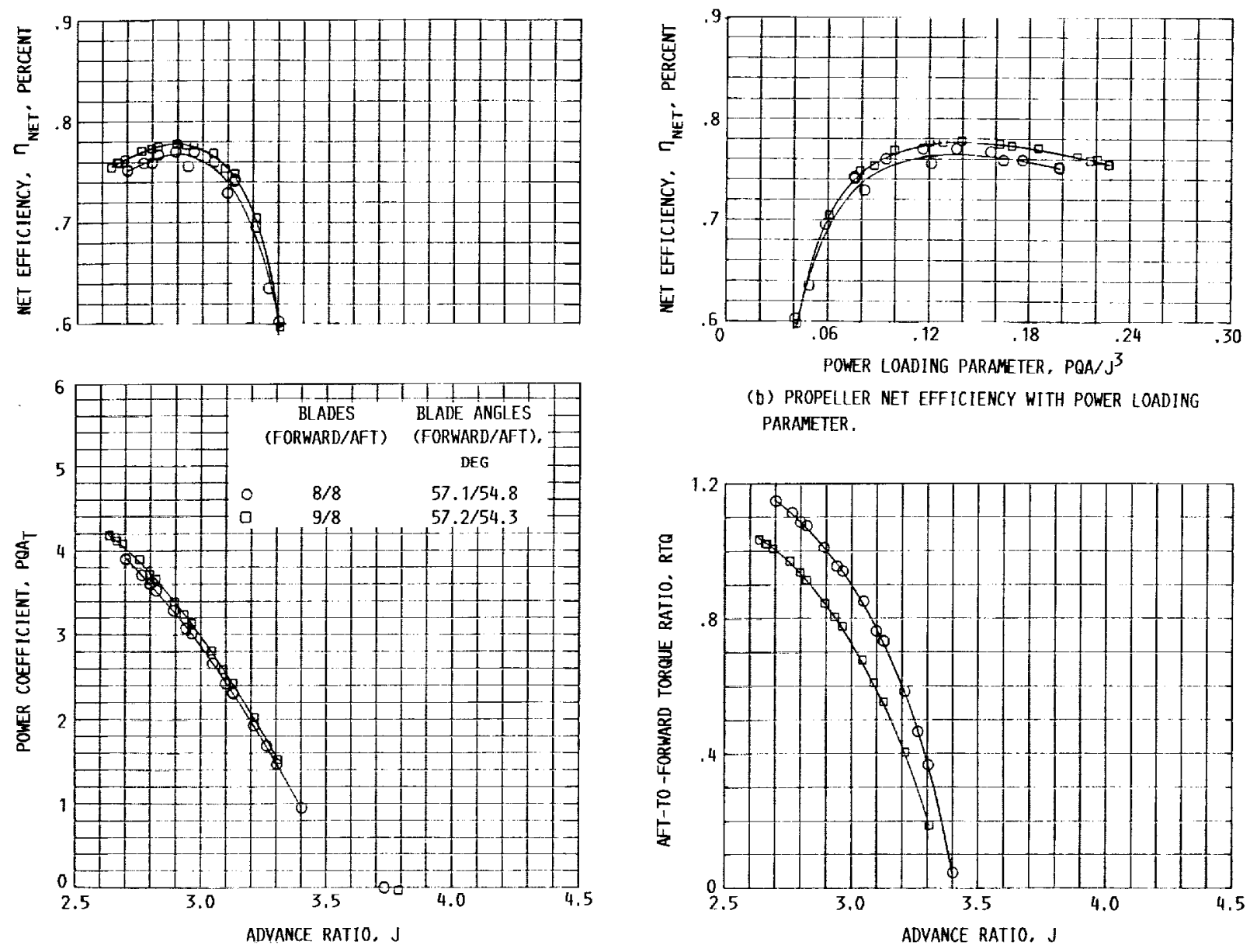

(a) PROPELLER NET EFFICIENCY AND POWER COEFFICIENT WITH ADVANCE RATIO.

FIGURE 9. - F1/A1 PERFORMANCE AT MACH 0.75 .

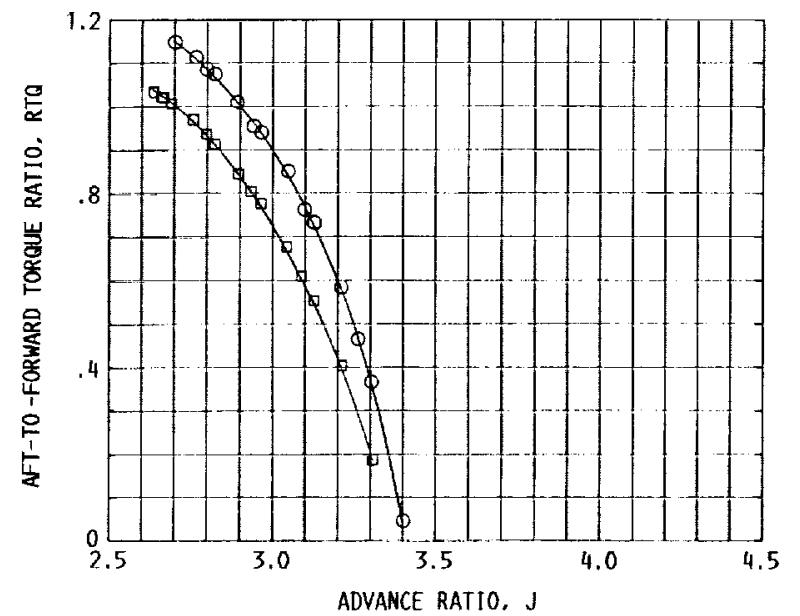

(c) AFT-T0-FORWARD TORQUE RATIO WITH ADVANCE RATIO. 

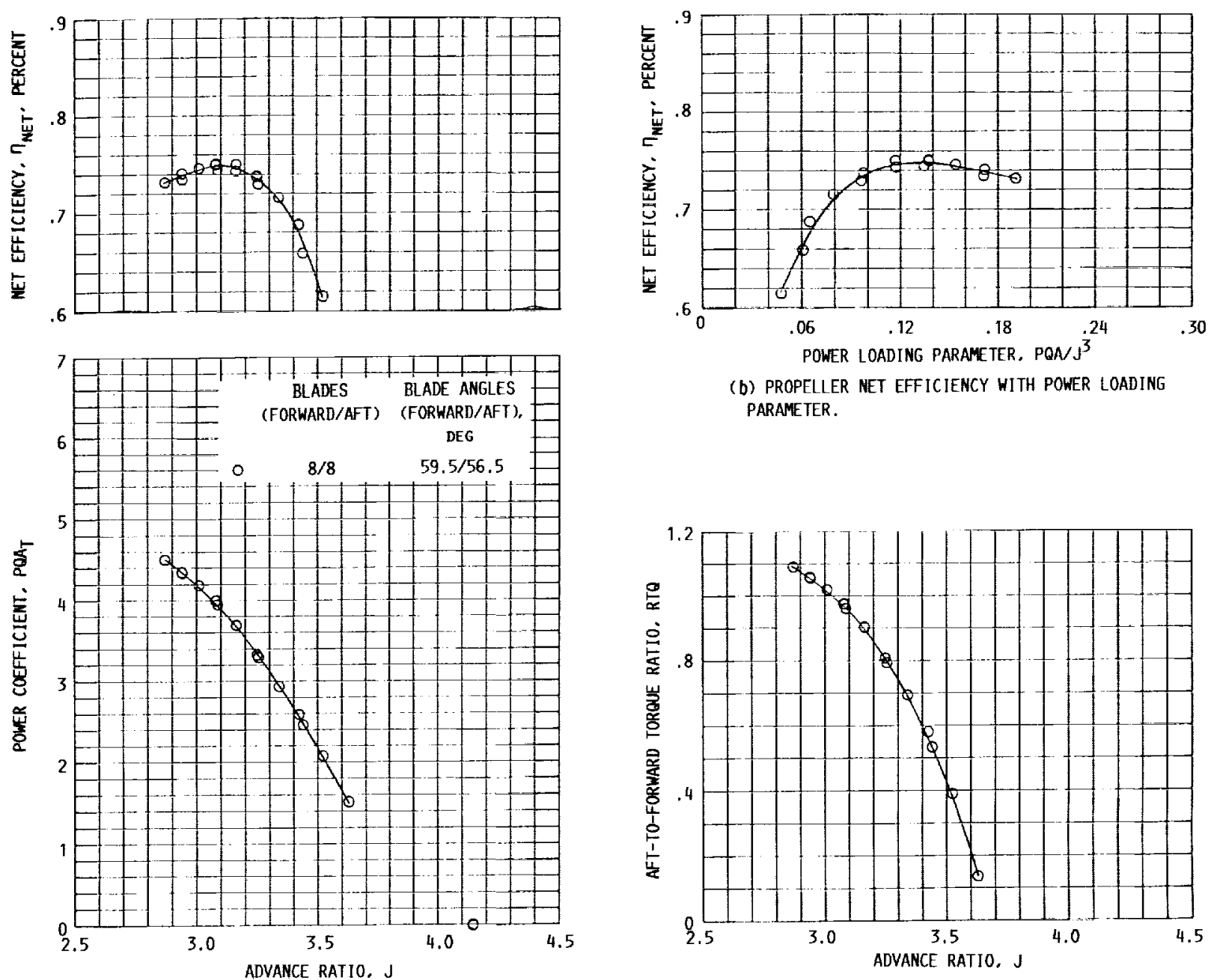

(a) PROPELLER NET EFFICIENCY AND POWER COEFFICIENT (b) PROPELLER NET EFFICIENCY WITH POWER LOADING PARAMETER.

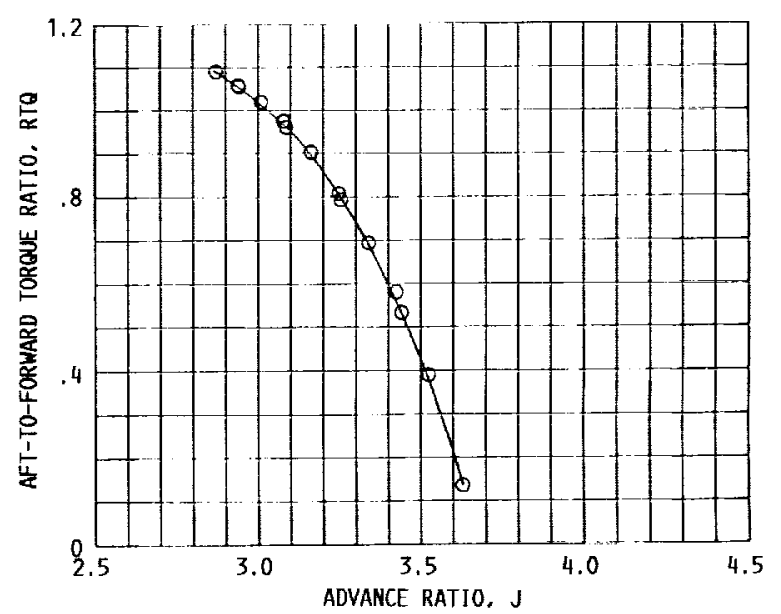

(c) AFT-TO-FORMARD TORQUE RATIO HITH ADVANCE RATIO. FIGURE 10. - F1/A1 PERFORMANCE AT MACH 0.79. 

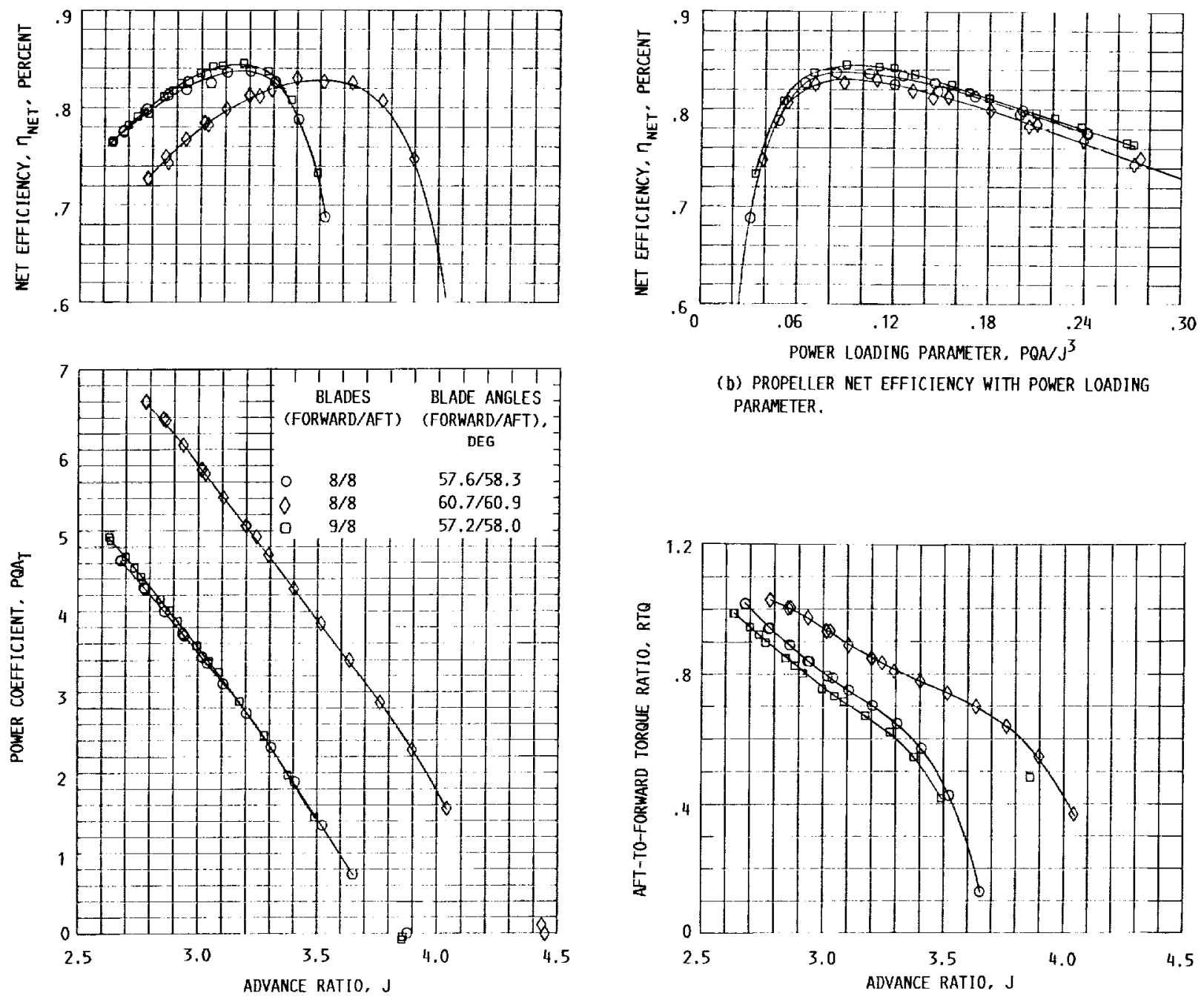

(a) PROPELLER NET EFFICIENCY AND POWER COEFFICIENT WITH ADVANCE RATIO.

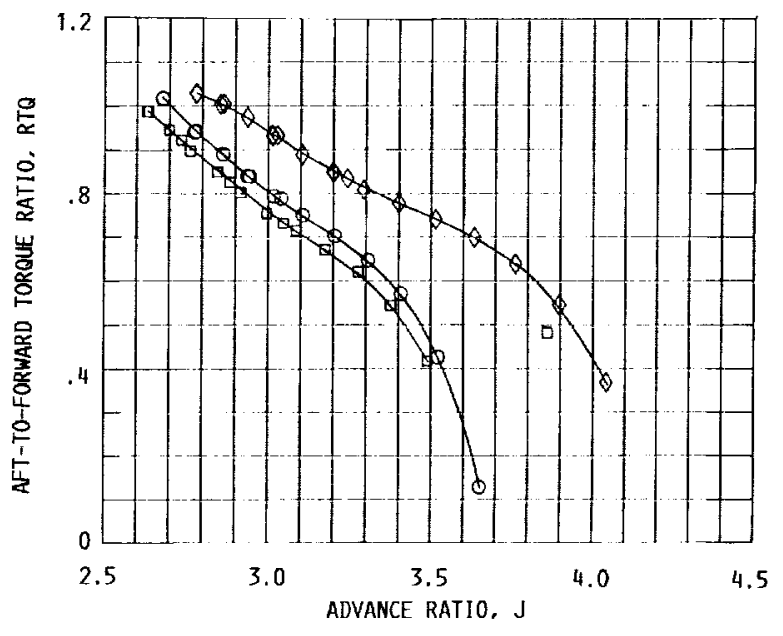
(c) AFT-TO-FORWARD TORQUE RATIO WITH ADVANCE RATIO.

FIGURE 11. - F1/A3 PERFORMANCE AT MACH 0.66. 

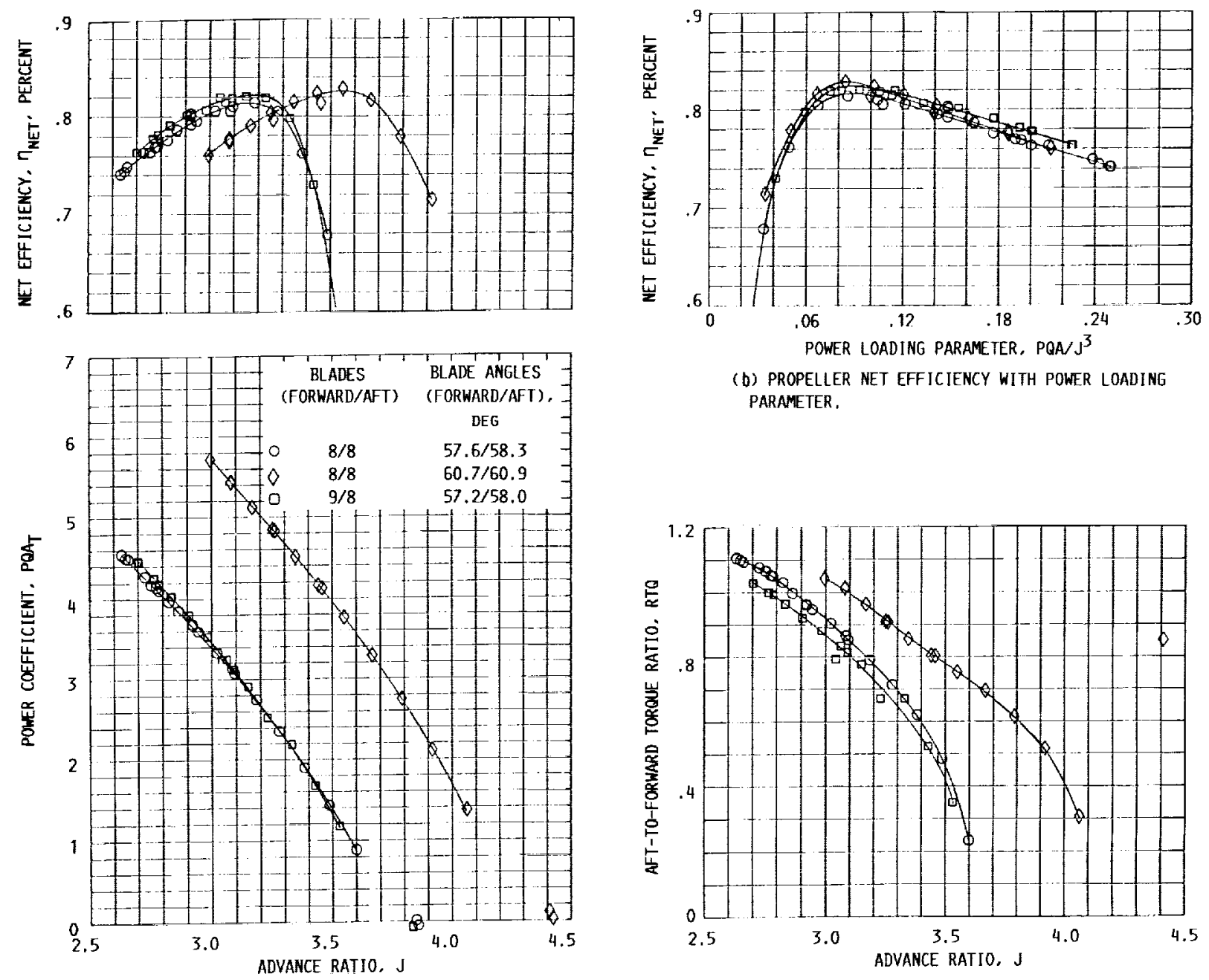

(a) PROPELLER NET EFFICIENCY AND POWER COEFFICIENT WITH ADVANCE RATIO.

FIGURE 12. - F1/A3 PERFORMANCE AT MACH 0.7T.

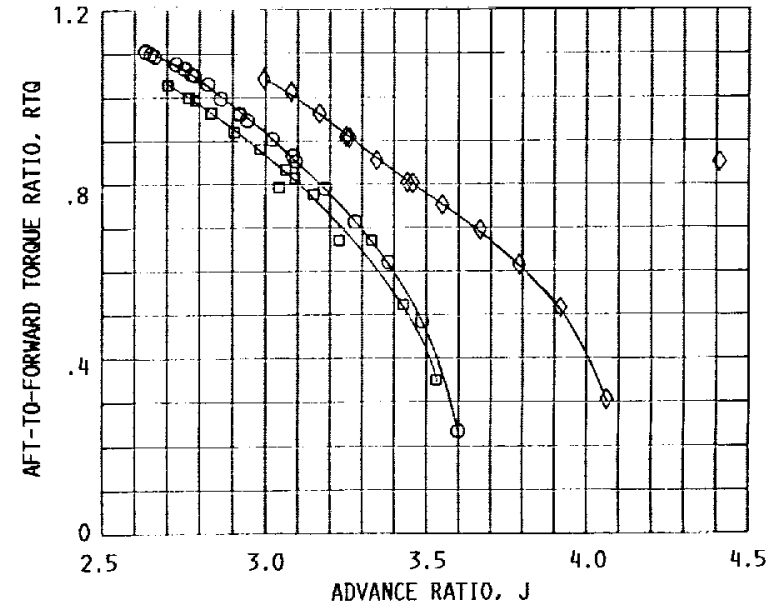

(c) AFT-TO-FORHARD TORQUE RATIO WITH ADVANCE RATIO. 

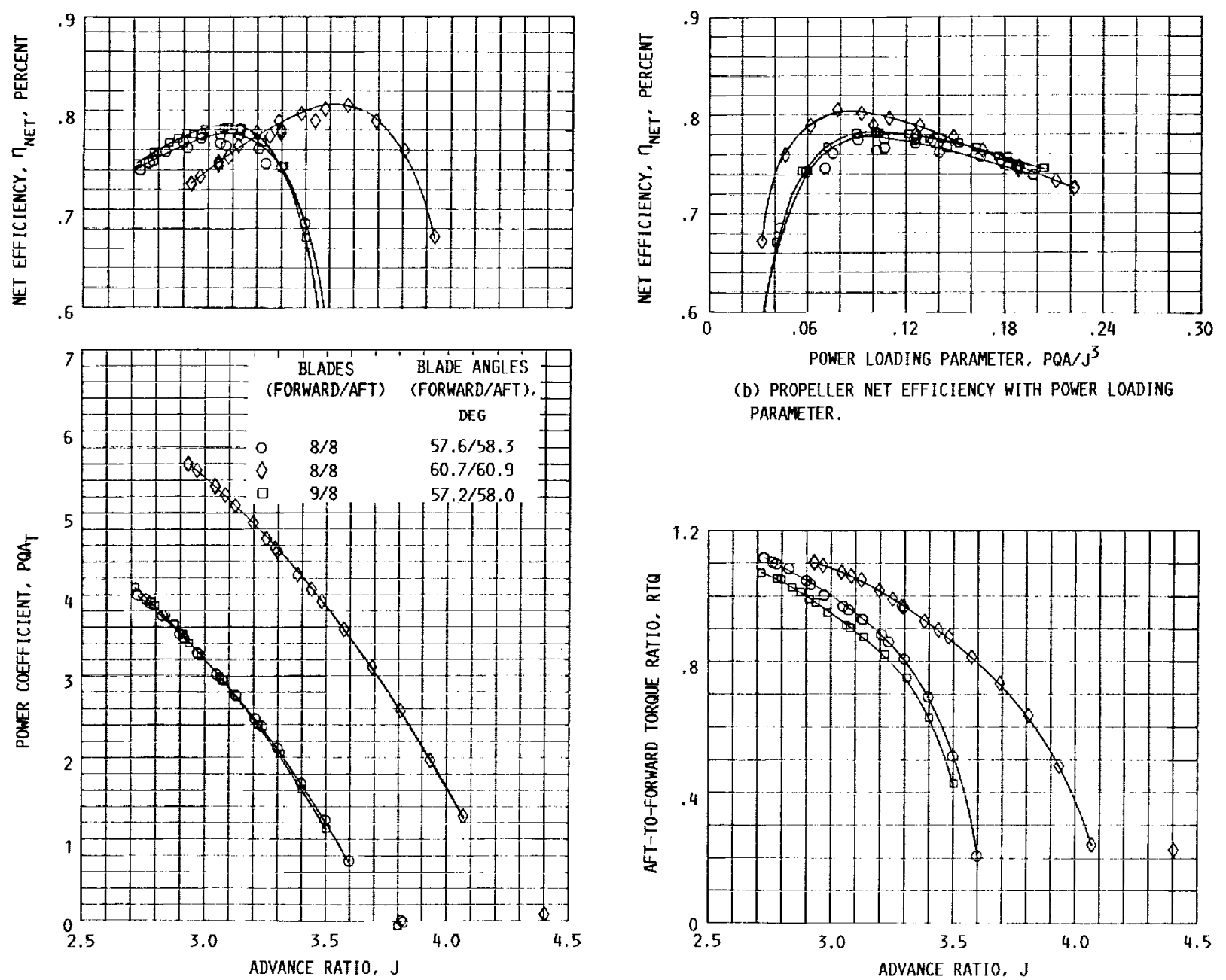

(a) PROPELLER NET EFFICIENCY AND POWER COEFFICIFNT WITH ADVANCE RATIO.

FIGURE 13. - F1/A3 PERFORMANCE AT MACH 0.75.

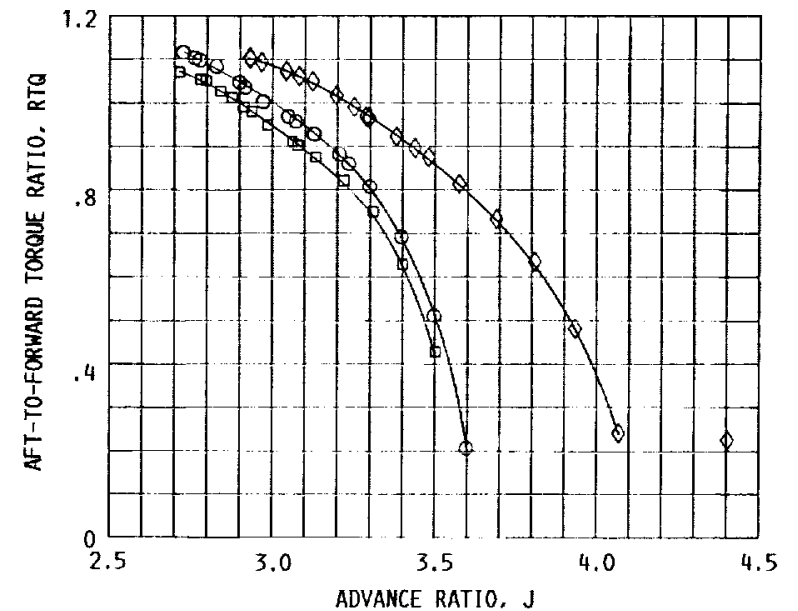

(c) AFT-TO-FORWARD TORQUE RATIO ADVANCE RATIO. 

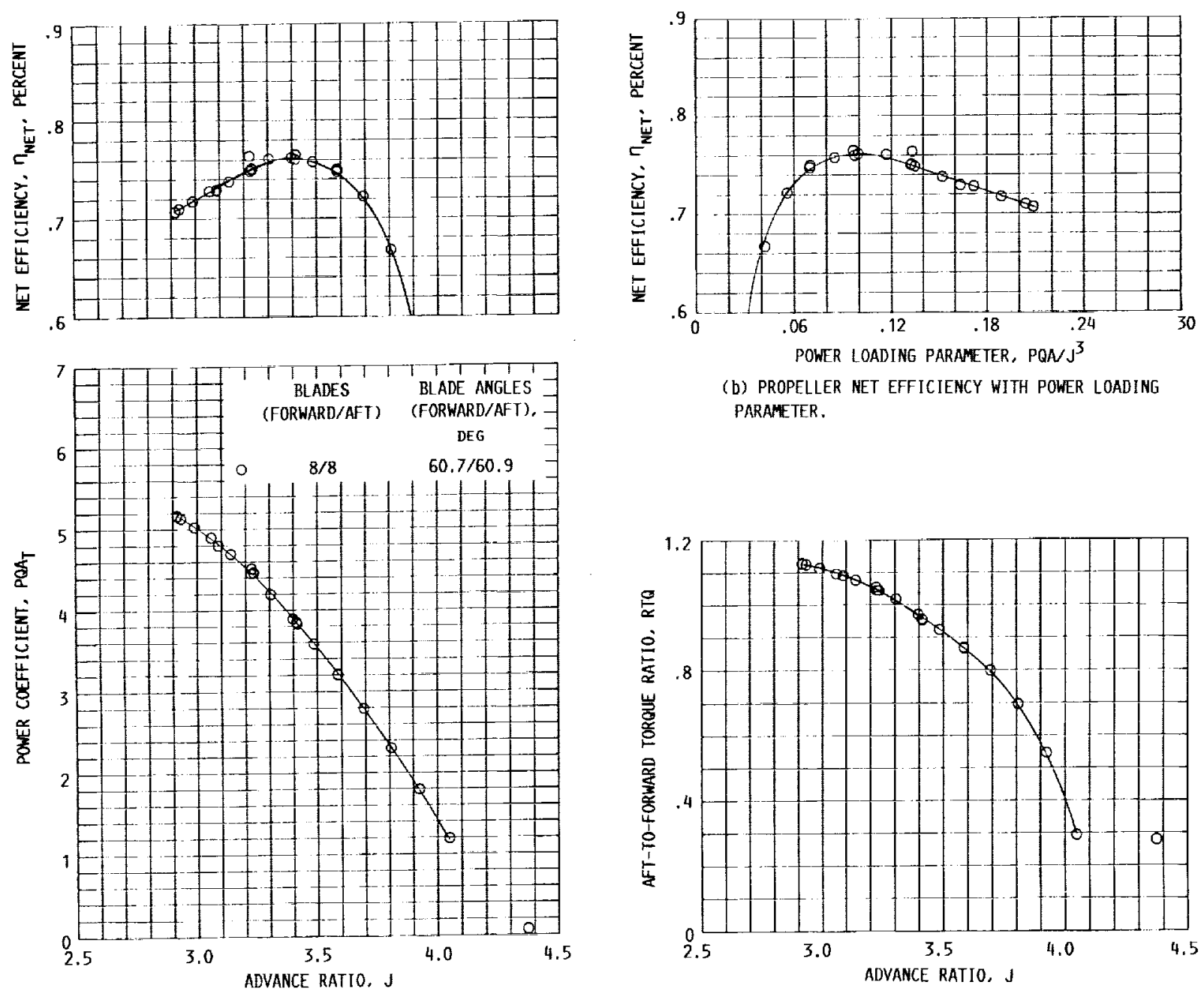

(a) PROPELLER NET EFFICIENCY AND POWER COEFFICIENT WITH ADVANCE RATIO.

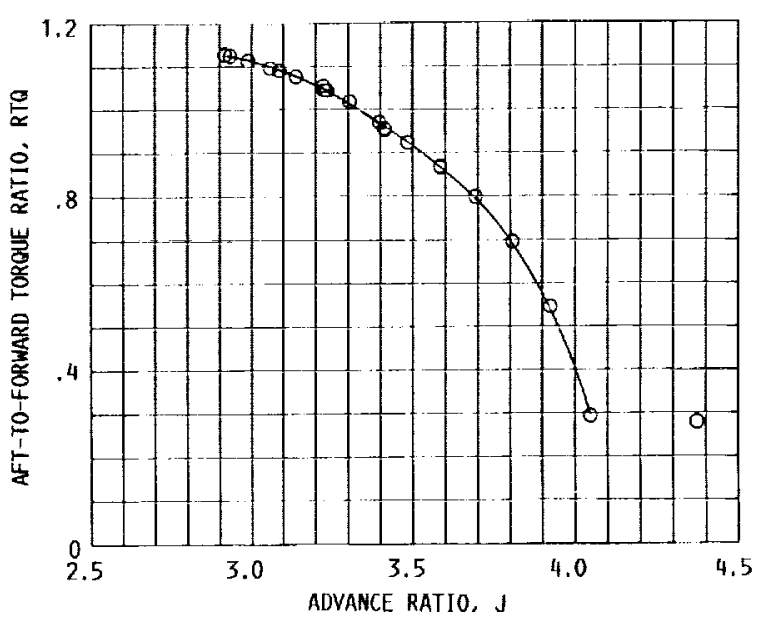

(C) AFT-TO-FORWARD TORQUE RATIO WITH ADVANCE RATIO.

FIGURE 14. - F1/A3 PERFORMANCE AT MACH 0.79. 

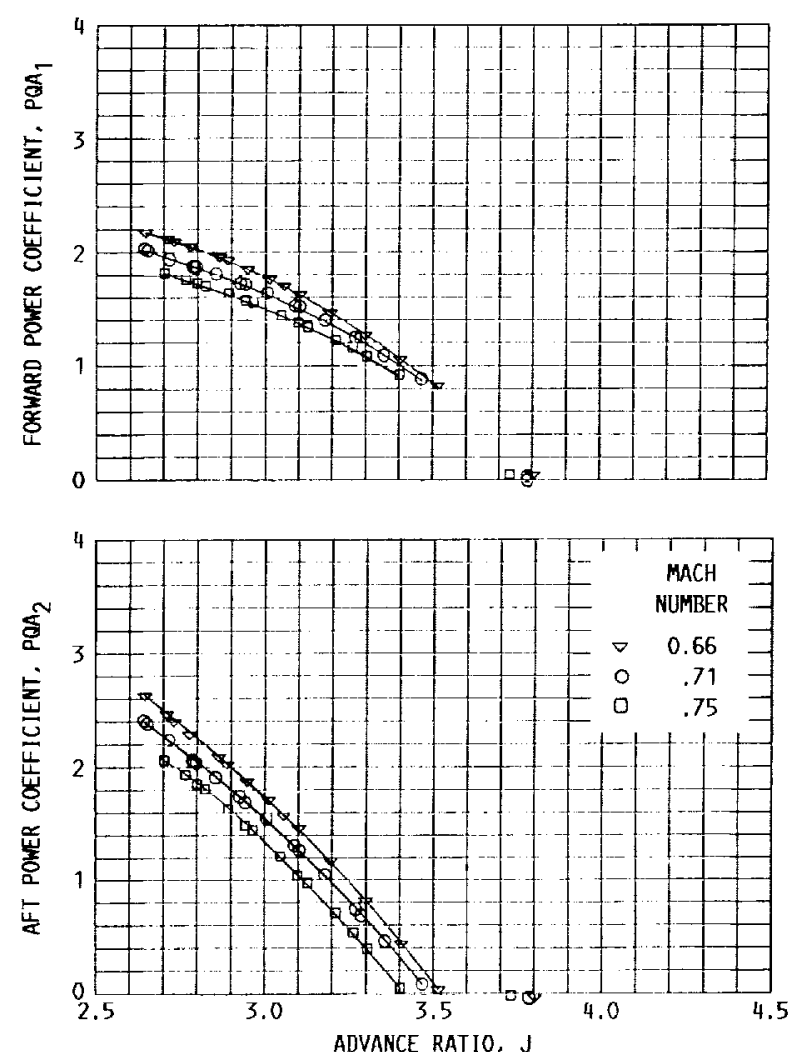

FIGURE 15. - F1/A1 8/8 INDIVIDUAL ROTOR POWER COEFFICIENT FOR BLADE ANGLES OF $\beta_{1}=57.1^{\circ}$ AND $\beta_{2}=54.8^{\circ}$ AT VRRIOUS MACH NUMBERS.
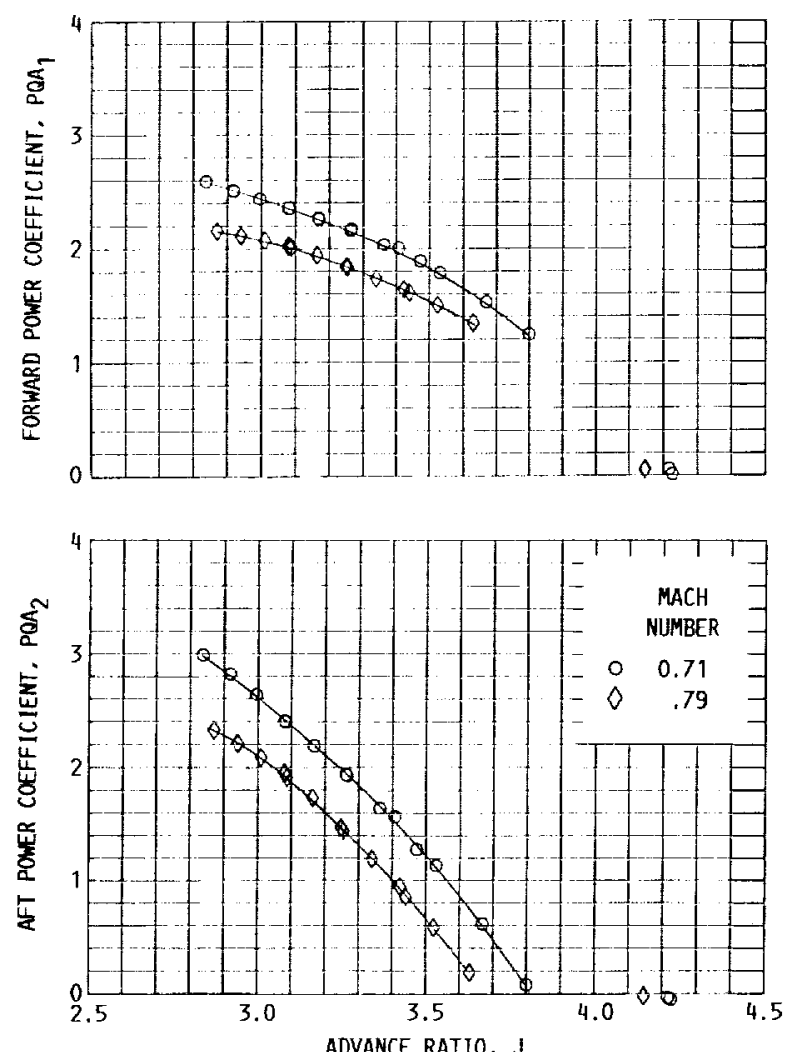
FIGURE 16. - F1/A1 8/8 INDIVIDUAL ROTOR POMER COEFFICIENT FOR BLADE ANGLES OF $\beta_{1}=59.5^{\circ}$ AND $\beta_{1}=56.5^{\circ}$ AT VARTOUS MACH NUMBERS. 

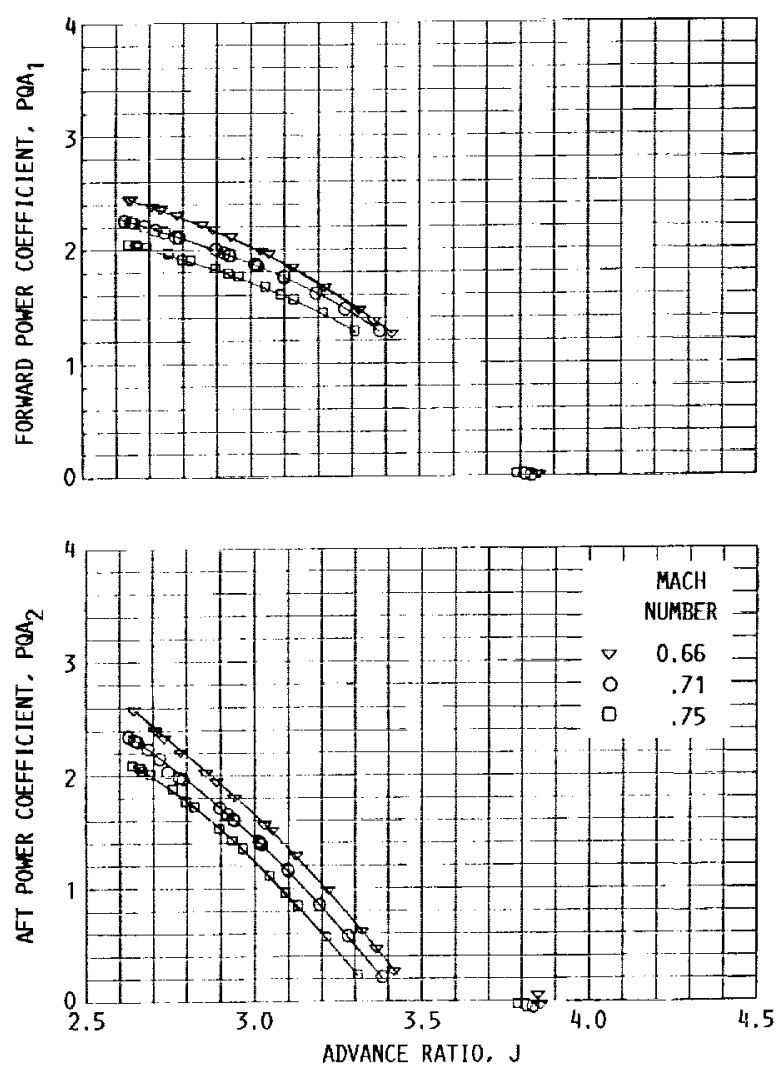

FIGURE 17 - F1/A1 9/8 INDIVIDUAL ROTOR POWER COEFFICIENT FOR BLADE ANGLES OF $\beta_{1}=57,2^{\circ}$ AND $\beta_{2}=54.3^{\circ}$ AT VARIOUS MACH NUMBERS.
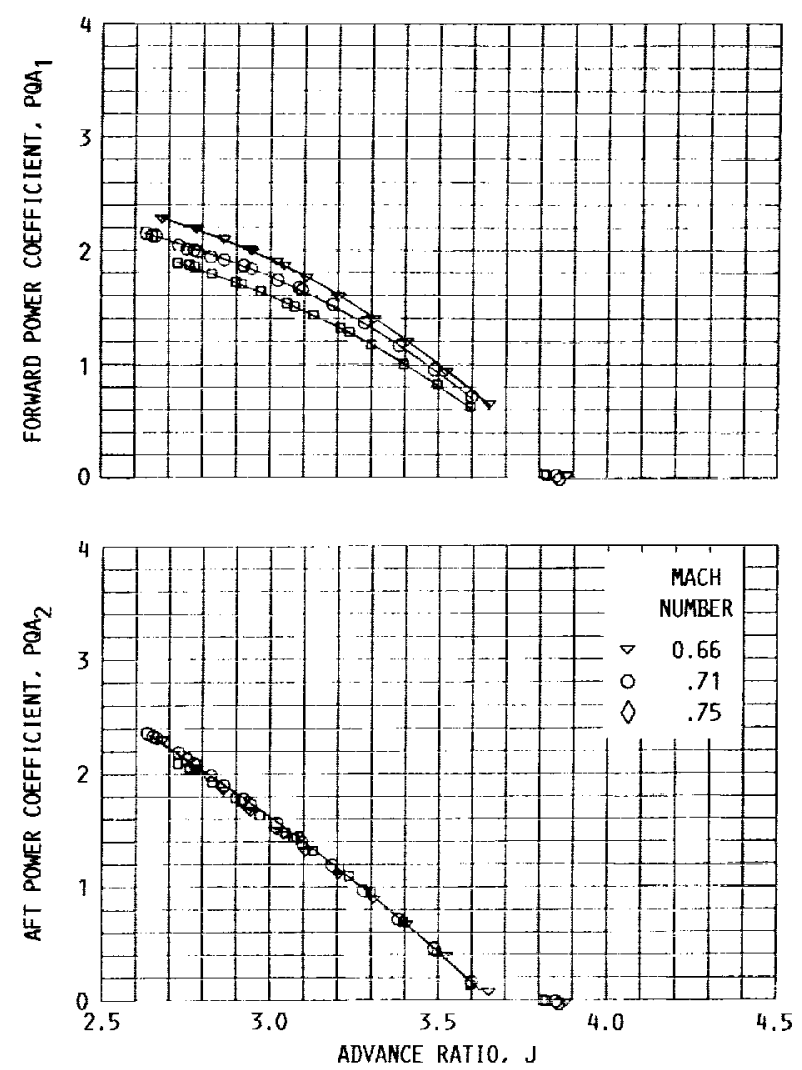

FIGURE 18. - F1/A3 8/8 INDIVIDUAL ROTOR POWER COEFFICIENT FOR BLADE ANGLES OF $\beta_{1}=57.6^{\circ}$ AND $\beta_{2}=58.3^{\circ}$ AT VARIOUS MACH NUMBERS. 

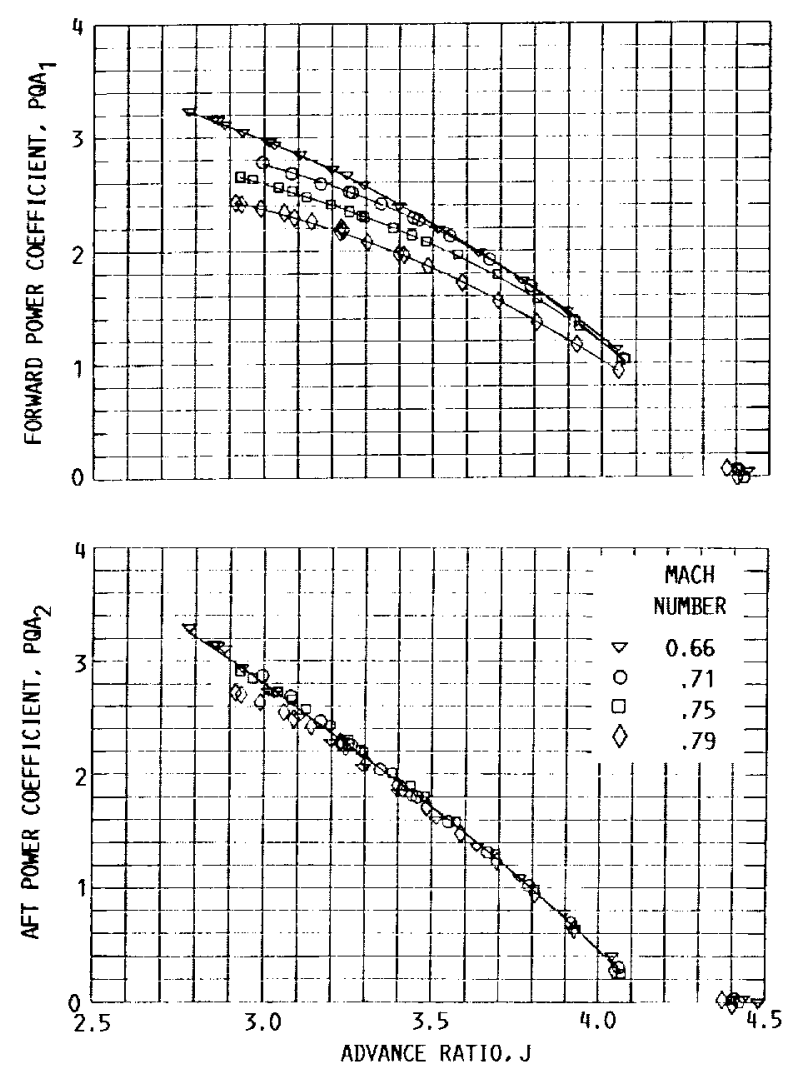

FIGURE 19. - F1/A3 8/8 INDIVIDUAL ROTOR POWER COEFFICIENT FOR BLADE ANGLES OF $\beta_{1}=60.7^{\mathrm{0}}$ AND $\beta_{2}=60.9^{\circ}$ AT VARIOUS MACH NUMBERS.
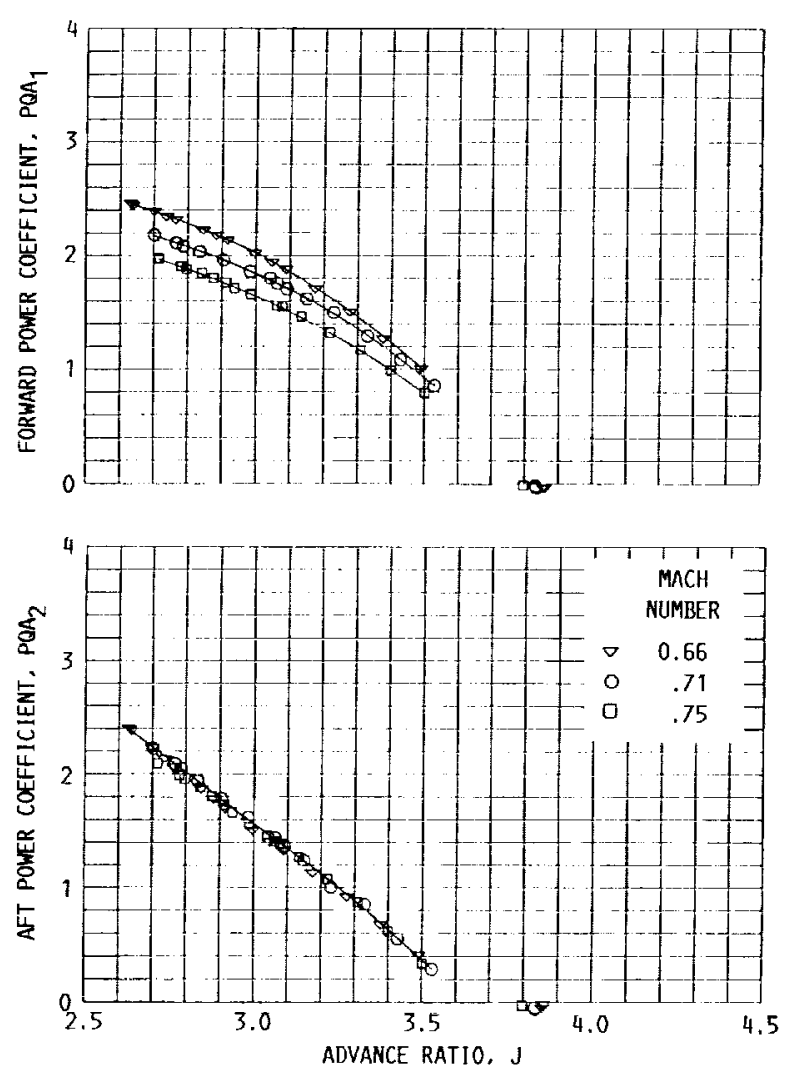

FIGURE 20. - F1/A3 9/8 INDIVIDUAL ROTOR POWER COEFFICIENT FOR BLADE ANGLES OF $\beta_{1}=57.2^{\circ}$ AND $\beta_{2}=58.0^{\circ}$ AT . VARIOUS MACH NUMBERS. 


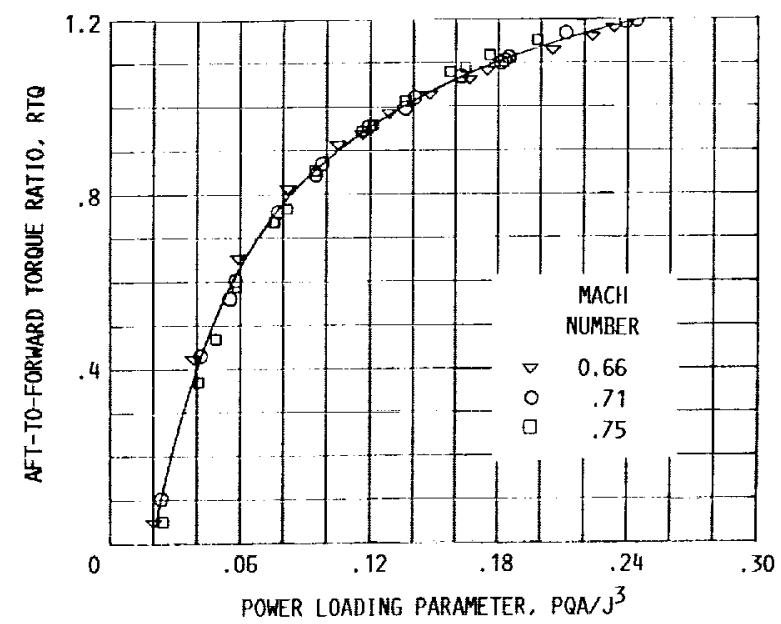

FIGURE 21. - F1/A1 8/8 TORQIE RATIO FOR BLADE ANGLES OF $\beta_{1}=57.1^{\circ}$ AND $\beta_{2}=54.8^{\circ}$ AT VARLOUS MACH NUMBERS.

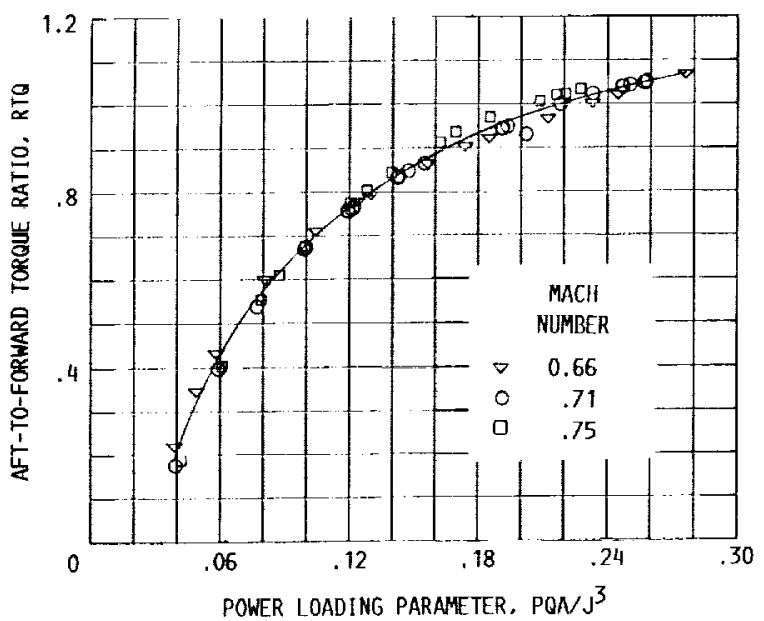

FIGURE 23. - F1/A1 9/8 TORQUE RATIO FOR BLADE ANGLES OF $\beta_{1}=57.2^{\circ}$ AND $\beta_{2}=54.3^{\circ}$ AT VARIOUS MACH NUMBERS.

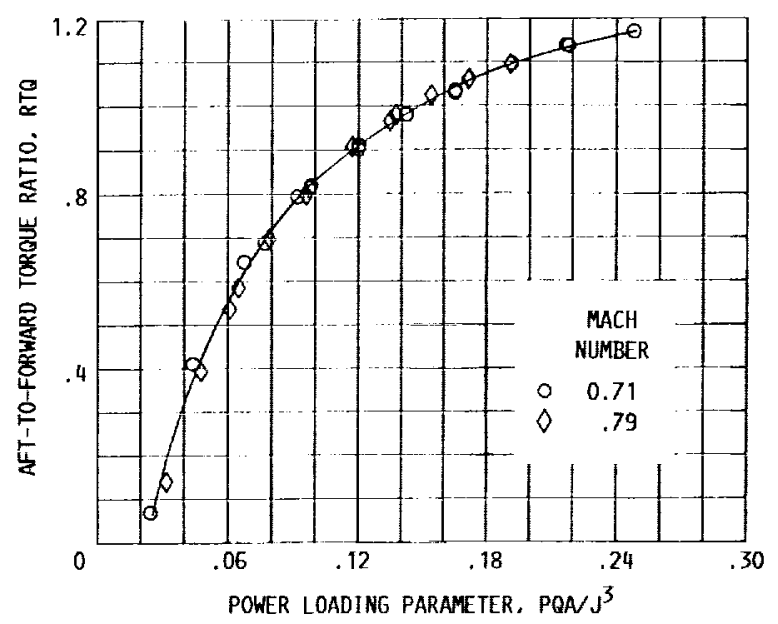

FIGURE 22. - F1/A1 8/8 TORQUE RATIO FOR BLADE ANGLES OF $\beta_{1}=59.5^{\circ}$ AND $\beta_{2}=56.5^{\circ}$ AT VARIOUS MACH NUMBERS.

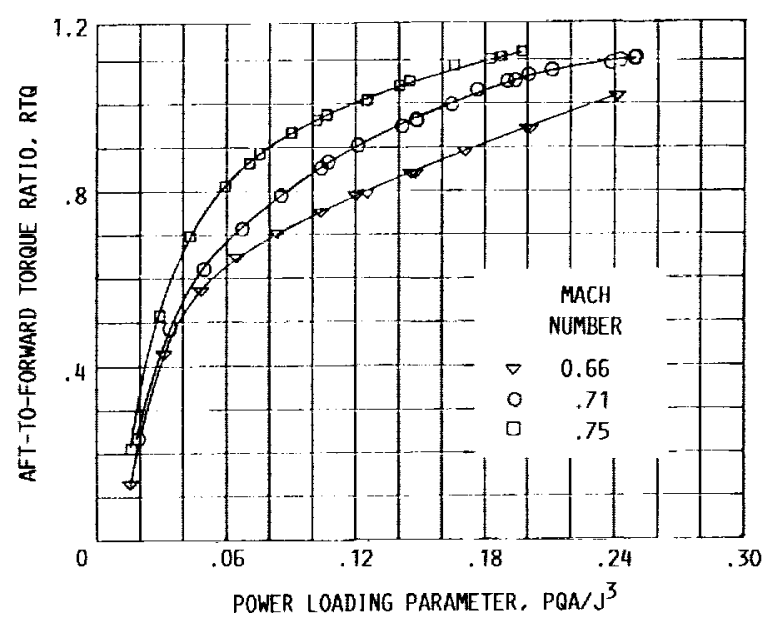

FIGURE 24. - F1/A3 8/8 TORQUE RATIO FOR BLADE ANGLES OF $\beta_{1}=57.6^{\circ}$ AND $\beta_{2}=58.3^{\circ}$ AT VARIOUS MACH NUMBERS. 


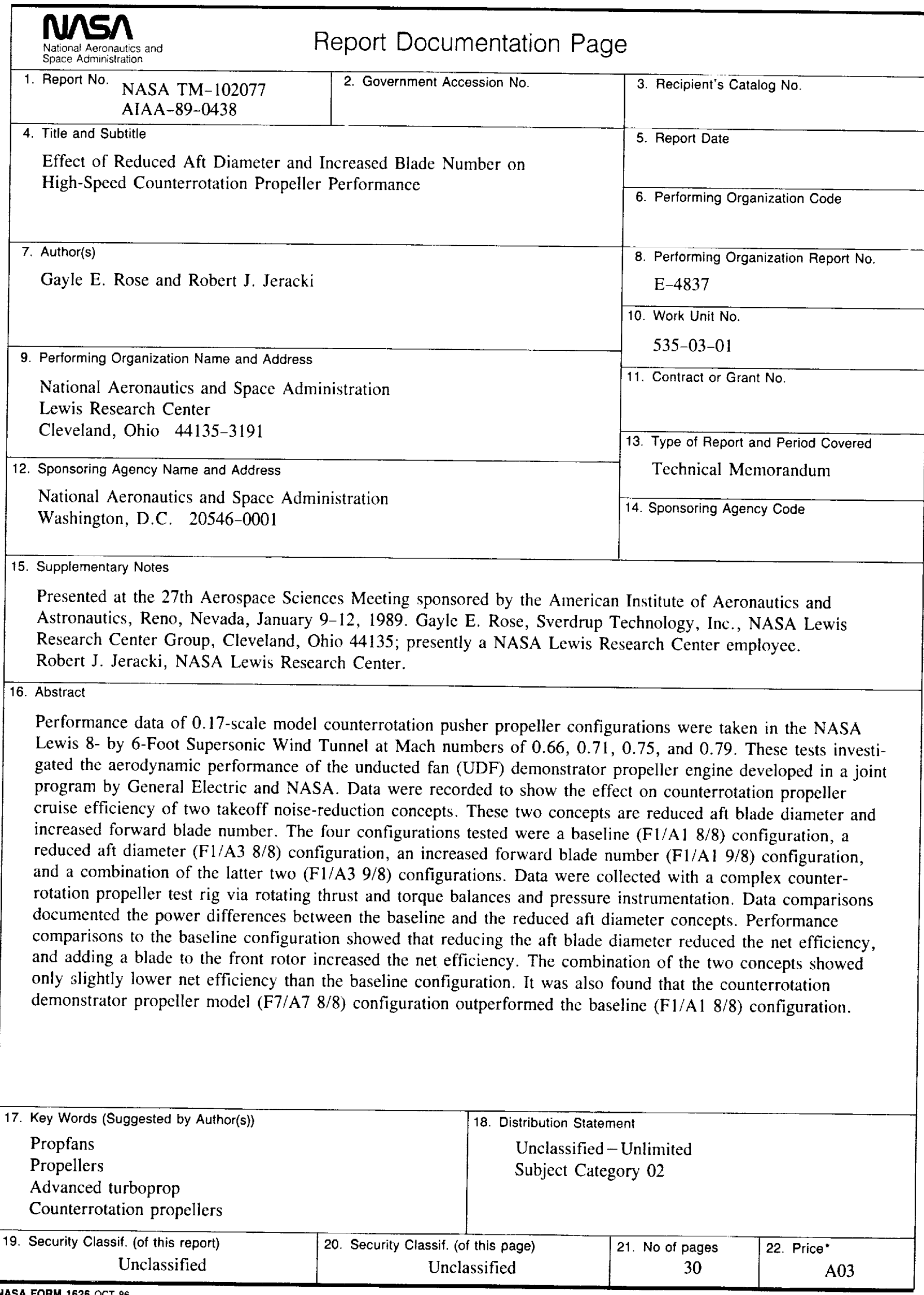




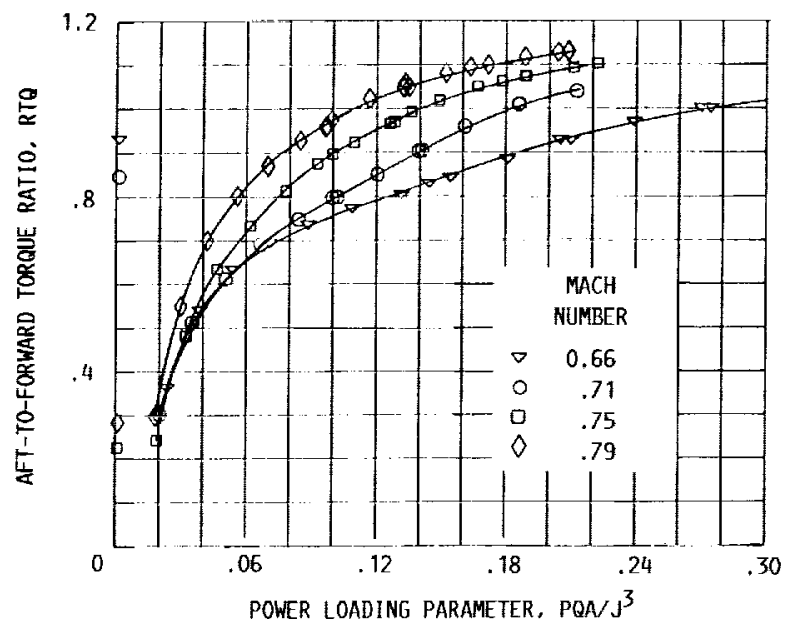

FIGURE 25. - F1/A3 8/8 TORQUE RATIO FOR BLNDE ANGLES OF $\beta_{1}=60.7^{\circ}$ AND $\beta_{2}=60.9^{\circ}$ AT VARIOUS MACH NUMBERS.

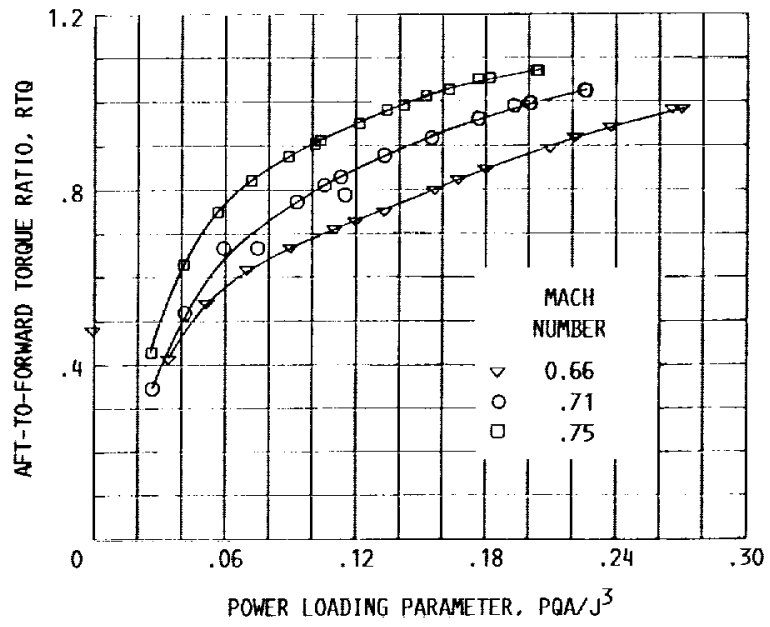

FIGURE 26, - F1/A3 9/8 TORQUE RATIO FOR BLADE ANGLES OF $\beta_{1}=57.2^{\circ}$ AND $\beta_{2}=58.0^{\circ}$ AT VARIOUS MACH NUMBERS.

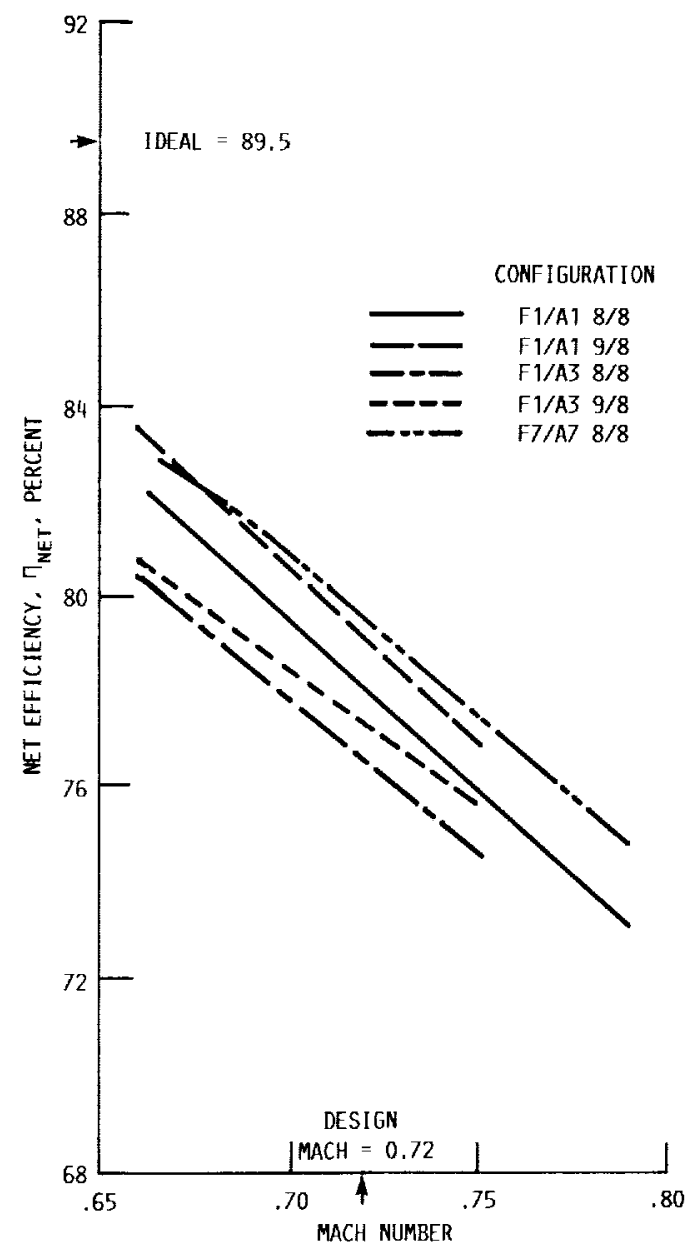

FIGURE 27. - FSTIMATED PERFORMANCE COMPARISONS AT CONSTANT POWER LOADING PARAMEIER $\left(\mathrm{PQA}_{T} / \mathrm{j}^{3}\right)$ OF 0.1875 . 